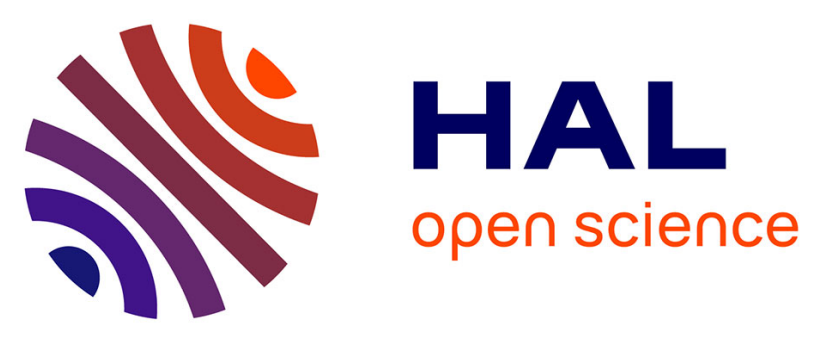

\title{
Residence time, mineralization processes and groundwater origin within a carbonate coastal aquifer with a thick unsaturated zone
}

Sébastien Santoni, Frédéric Huneau, Emilie Garel, Virginie Vergnaud-Ayraud, Thierry Labasque, Luc Aquilina, Jessy J. Jaunat, Hélène Celle-Jeanton

\section{To cite this version:}

Sébastien Santoni, Frédéric Huneau, Emilie Garel, Virginie Vergnaud-Ayraud, Thierry Labasque, et al.. Residence time, mineralization processes and groundwater origin within a carbonate coastal aquifer with a thick unsaturated zone. Journal of Hydrology, 2016, 540, pp.50-63. 10.1016/j.jhydrol.2016.06.001 . insu-01328624

\section{HAL Id: insu-01328624 https://hal-insu.archives-ouvertes.fr/insu-01328624}

Submitted on 8 Jun 2016

HAL is a multi-disciplinary open access archive for the deposit and dissemination of scientific research documents, whether they are published or not. The documents may come from teaching and research institutions in France or abroad, or from public or private research centers.
L'archive ouverte pluridisciplinaire HAL, est destinée au dépôt et à la diffusion de documents scientifiques de niveau recherche, publiés ou non, émanant des établissements d'enseignement et de recherche français ou étrangers, des laboratoires publics ou privés. 


\section{Accepted Manuscript}

Residence time, mineralization processes and groundwater origin within a carbonate coastal aquifer with a thick unsaturated zone

S. Santoni, F. Huneau, E. Garel, V. Vergnaud-Ayraud, T. Labasque, L. Aquilina, J. Jaunat, H. Celle-Jeanton

PII:

S0022-1694(16)30352-3

DOI: http://dx.doi.org/10.1016/j.jhydrol.2016.06.001

Reference:

HYDROL 21319

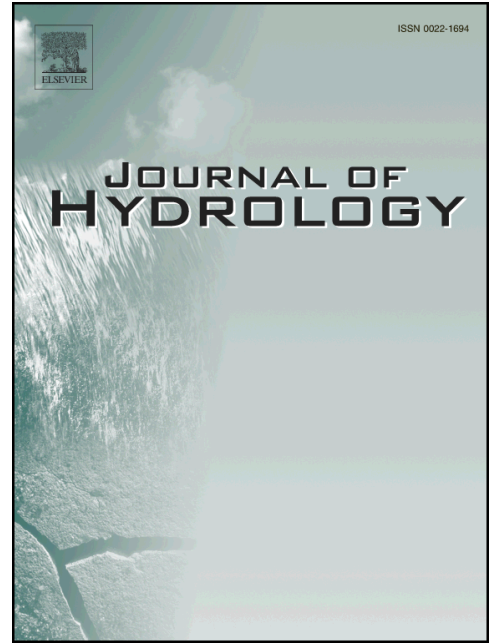

To appear in:

Journal of Hydrology

Received Date:

26 October 2015

Revised Date:

7 April 2016

Accepted Date:

1 June 2016

Please cite this article as: Santoni, S., Huneau, F., Garel, E., Vergnaud-Ayraud, V., Labasque, T., Aquilina, L., Jaunat, J., Celle-Jeanton, H., Residence time, mineralization processes and groundwater origin within a carbonate coastal aquifer with a thick unsaturated zone, Journal of Hydrology (2016), doi: http://dx.doi.org/10.1016/j.jhydrol. 2016.06.001

This is a PDF file of an unedited manuscript that has been accepted for publication. As a service to our customers we are providing this early version of the manuscript. The manuscript will undergo copyediting, typesetting, and review of the resulting proof before it is published in its final form. Please note that during the production process errors may be discovered which could affect the content, and all legal disclaimers that apply to the journal pertain. 


\title{
Residence time, mineralization processes and groundwater origin within a carbonate coastal aquifer with a thick unsaturated zone
}

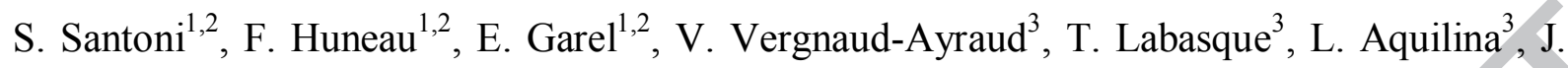 \\ Jaunat $^{4}$, H. Celle-Jeanton ${ }^{5}$ \\ ${ }^{1}$ Université de Corse Pascal Paoli, Faculté des Sciences et Techniques, Laboratoire d'Hydrogéologie, \\ Campus Grimaldi, BP 52, F-20250 Corte, France \\ ${ }^{2}$ CNRS, UMR 6134, SPE, F-20250 Corte, France \\ ${ }^{3}$ OSUR, Géosciences Rennes, UMR 6118, CNRS/Université Rennes-1, F-35042 Rennes, France. \\ ${ }^{4}$ Université de Reims Champagne-Ardenne, EA 3795 - GEGENAA, 2 esplanade Roland Garros, F- \\ 51100 Reims, France. \\ ${ }^{5}$ Université de Franche-Comté, UFR Sciences et Techniques, CNRS UMR 6249 Chrono- \\ Environnement, 16 route de Gray, F-25 030 Besançon Cedex, France
}

\begin{abstract}
This study aims at establishing groundwater residence times, identifying mineralization processes and determining groundwater origins within a carbonate coastal aquifer with thick unsaturated zone and lying on a granitic depression. A multi-tracer approach (major ions, $\left.\mathrm{SiO}_{2}, \mathrm{Br}^{-}, \mathrm{Ba}^{+}, \mathrm{Sr}^{2+},{ }^{18} \mathrm{O},{ }^{2} \mathrm{H},{ }^{13} \mathrm{C},{ }^{3} \mathrm{H}, \mathrm{Ne}, \mathrm{Ar}\right)$ combined with a groundwater residence time determination using $\mathrm{CFCs}$ and $\mathrm{SF}_{6}$ allows defining the global setting of the study site. A typical mineralization conditioned by the sea sprays and the carbonate matrix helped to validate the groundwater weighted residence times from using a binary mixing model. Terrigenic $\mathrm{SF}_{6}$ excesses have been detected and quantified, which permits to identify a groundwater flow from the surrounding fractured granites towards the lower aquifer principally. The use of CFCs and $\mathrm{SF}_{6}$ as a first hydrogeological investigation tool is possible and very relevant despite the thick unsaturated zone and the hydraulic connexion with a granitic environment.
\end{abstract}

\section{Key words}

Residence time, $\mathrm{CFCs}_{2} \mathrm{SF}_{6}$, coastal aquifer, flow pattern, Corsica

\section{Introduction}

The residence time of groundwater is a fundamental parameter for the understanding of hydrogeosystems functioning (McCallum et al., 2014; Suckow, 2014). Indeed, the groundwater residence time documents on contaminant transport and sustainability of water 
resources (Baudron et al., 2014; Cook et al., 1995; Cook and Herczeg, 2000; Gourcy et al., 2009; Murgulet et al., 2016; Vautour et al., 2015). It is also a powerful integrative approach of groundwater origin and flow path organisation within aquifers (Anders et al., 2014; Bertrand et al., 2010; Gooddy et al., 2006; Jaunat et al., 2012; Kamtchueng et al., 2015). Furthermore, groundwater residence time provides information to constrain recharge area, discharge rate, flow directions and velocities, all necessary to either quantitatively validate a numerical or conceptual hydrogeological model (Aquilina et al., 2014; Post et al., 2013; Turnadge and Smerdon, 2014; Zuber et al., 2005). When groundwater residence times are over timescale of 0-70 years, dating tools such as tritium, chlorofluorocarbons (CFCs) or sulphur hexafluoride $\left(\mathrm{SF}_{6}\right)$ may be used (Aeschbach-Hertig et al., 1998; Alvarado et al., 2005; Cook and Solomon, 1997; Corcho Alvarado et al., 2007; Delbart et al., 2014). Due to the stabilization of ${ }^{3} \mathrm{H}$ concentrations around $10 \mathrm{TU}$ in the atmosphere since the $1970 \mathrm{~s}$, tritium dating has lost precision (Blavoux et al., 2013). CFCs and $\mathrm{SF}_{6}$ are anthropogenic atmospheric gases. In groundwater, their presence indicates a recharge after 1950 or a mixing with older waters (Busenberg and Plummer, 1992). Atmospheric $\mathrm{SF}_{6}$ concentration has been continuously increasing since the 1960s whereas CFCs concentrations stopped increasing since the Montreal and Kyoto protocols (1986-1992). However a sample taken at a given location is often a mixture of waters that have been transported via various flow paths. Thus this residence time should be mostly interpreted as a weighted mean of idealized residence times (Bethke and Johnson, 2008; Goode, 1996; Jodar et al., 2014; Suckow, 2014; Torgersen et al., 2013; Turnadge and Smerdon, 2014). The major advantage of CFCs and $\mathrm{SF}_{6}$ resides in the possibility to discriminate different water bodies considering various mixing models (piston flow, binary or exponential), providing information on aquifer functioning (Cook et al., 1995; Jodar et al., 2014; Kashiwaya et al., 2014; Zuber et al., 2005). CFCs and $\mathrm{SF}_{6}$ are commonly considered as pertinent dating tracers but there are nevertheless some limits to their use (Kashiwaya et al., 2014). CFCs may be affected by the transfer processes in the unsaturated zone, local contaminations and degradation processes in anoxic environments causing most of the time offsets to groundwater aging (Aeschbach-Hertig et al., 1998; Beyerle et al., 1999; Gooddy et al., 2006; Gourcy et al., 2009; Heaton and Vogel, 1981; Schwientek et al., 2009). $\mathrm{SF}_{6}$ is considered as a conservative tracer, but natural sources have been highlighted in granitic environments and some carbonates aquifers (Han et al., 2014; Harnisch and Eisenhauer, 1998; Harnisch et al., 2000). As a consequence, it appears difficult to employ CFCs and $\mathrm{SF}_{6}$ as groundwater dating tracers in presence of thick unsaturated zone, particularly if aquifers are hydraulically connected to granitic environments. 
Many studies have been carried out in coastal aquifers using successfully $\mathrm{CFCs}_{\text {and }} \mathrm{SF}_{6}$ as groundwater residence times and mixing tracers (Gilmore et al., 2016; Kashiwaya et al., 2014; Kelly and Glenn, 2015; Lee, 2014) but none of them concerned aquifers with strong geological contrast and deep unsaturated zone. Investigations have been carried out within the coastal Miocene plateau of Bonifacio (Corsica, France), most visited place of the island hosting more than two million tourists each year. This aquifer is mainly composed of calcarenites lying on fractured granitic formations, and includes an unsaturated zone up to 50 meters thick. It thus corresponds to an interesting study site to test the groundwater dating tools potential. A well-documented description of the geology and structure of this basin was the starting point for a detailed study of residence time, mineralization processes and groundwater origin within this carbonate coastal aquifer with a thick unsaturated zone. The strategy chosen for the study of this hydrosystem is a multi-tracing approach combining major ions, $\mathrm{SiO}_{2}, \mathrm{Br}^{-}, \mathrm{Ba}^{+}, \mathrm{Sr}^{2+},{ }^{18} \mathrm{O},{ }^{2} \mathrm{H},{ }^{13} \mathrm{C},{ }^{3} \mathrm{H}, \mathrm{Ne}$, Ar with CFC-11, CFC-12, CFC-113 and $\mathrm{SF}_{6}$. The groundwater mineralization processes such as water-rock interactions, marine signature and anthropogenic influences will be clarified using stable isotopes, physico-chemical parameters and hydrogeochemical tracers before comparison with the $\mathrm{c}$ groundwater residence time determination using $\mathrm{CFCs}$ and $\mathrm{SF}_{6}$. In addition to improve the scope of $\mathrm{CFC}$ and $\mathrm{SF}_{6}$ as groundwater dating tracers, this study is expected to conclude on a description of the aquifer functioning in terms of groundwater mineralization, origins, flow paths and mixings through the establishment of a conceptual model. Indeed, this should highlight the relevance of such approach for complex hydrosystems. .

\section{Site description}

\subsection{Geography, geomorphology and land uses}

The Bonifacio plateau is situated in the southeast part of Corsica (western Mediterranean, France) bounded in equal proportions by granites at the east and the west and by the Mediterranean Sea at the Northeast and South (Fig. 1). Its triangular shape extends over an area of approximately $25 \mathrm{~km}^{2}$, with a mean elevation of 80 masl. The carbonate plateau fills a granitic depression and is surrounded by granitic relief with an altitude up to $250 \mathrm{~m}$ at the Mont de la Trinité (west side) and up to $110 \mathrm{~m}$ at San Mulari (east side). The plateau is cut by four East-West valleys: St. Julien, St. Jean, Canali and Canettu. The Canali River is the only perennial river with very low flow (Alamy and Chiari, 2010). Some coastal wetlands are 
present in Balistra, Canettu and Sperone. The 3,000 inhabitants of Bonifacio are living along the two main St. Julien and Saint Jean valleys. Some scarce goat and sheep farming or gardening activities are present in the centre of the plateau, in Padurella and Campagro, but the major part of the area is covered with Mediterranean maquis.

\subsection{Hydroclimatology}

The southern Corsica is characterized by a typical Mediterranean climate. Climatic conditions are very heterogeneous from one year to another one. The mean annual temperature and precipitation at the Bonifacio (Capo Pertusato, Fig. 1) Meteo France station are $16.8^{\circ} \mathrm{C}$ and $605 \mathrm{~mm}$ respectively (calculated from 01/2000 to 01/2012). The mean potential evapotranspiration calculated for the 01/2006-12/2014 period using the Turc formula (radiation and humidity data provided by Meteo France) is about $2590 \mathrm{~mm} / \mathrm{a}$. The estimated mean annual aquifer recharge is about $118 \mathrm{~mm} / \mathrm{a}$, which would represent $15 \%$ of the total precipitation on the Bonifacio plateau. This value seems a little overestimated regarding to the values between 52 to $86 \mathrm{~mm} / \mathrm{a}$ observed in neighbouring Sardinia (Ghiglieri et al., 2014). In the sector of Bonifacio wind blows 300 days per year, often with gusts above $60-80 \mathrm{~km} / \mathrm{h}$. These winds are causing heavy swell and generate significant sea sprays all over the study area.

\subsection{Geology}

The Bonifacio carbonate aquifer is developed in a sedimentary Miocene basin laying on a fractured Hercynian granitic depression (Fig.1 and 2). Several stratigraphic logs were defined in the area (Ferrandini et al., 2003; Orsini et al., 2010; Reynaud et al., 2012), showing three major sedimentary formations with little differences in the deposit sequences. In this paper, we refer to the stratigraphic log of Reynaud et al. (2012).

\subsubsection{Hercynian granitic depression}

The basement of the Bonifacio basin is made of a granitic bedrock dating from the Hercynian (-347 to -278 Myr) and locally known as the Corsican calco-alcaline batholith (Rossi, 1987). It is composed mainly of monzogranite and leucomonzogranite, coarse or fine grained. The granites were affected by intense fracturing during the Corsica-Sardinia Miocene block rotation (Gattacceca et al., 2007). Magma injections from the Miocene calco-alcaline volcanism (-20 to $-18 \mathrm{Myr})$ are present in the granite and correspond to dolerite veins in the 
West side of the plateau and pegmatite veins in the East side (Orsini et al., 2010). These intrusions are potential sources of fluoride and terrigenic $\mathrm{SF}_{6}$.

\subsubsection{Miocene sedimentary formations}

The Bonifacio sedimentary basin is composed, from the base to the top, of the Balistra, Cala di Labra and Bonifacio formations. The Balistra formation (Aquitanian) is a continental formation with a maximum thickness of $100 \mathrm{~m}$. It is composed at the base of fluvial detrital series including weathering products of the surrounding granites with a carbonated fraction (Orsini et al., 2010), and of ignimbritic tufa series a few meter thick at the top (Deino et al., 2001; Ottaviani-Spella et al., 2001). The Cala di Labra and Bonifacio formations forms a second set composed of carbonate marine sediments. The Cala di Labra formation (Burdigalian) can reach $90 \mathrm{~m}$ thick (Orsini et al., 2010). Three different levels are identified: shelly litharenites, a sandy silt level (materializing the separation between the upper and lower aquifer) and coralline-rich calcarenites (Reynaud et al., 2012). This formation was also fed by abundant near shore siliciclastic sediments (Tomassetti et al., 2012). The Bonifacio formation (Langhian) can reach $110 \mathrm{~m}$ thick. At the base, the Pertusato member is made of calcareous sandstones and sandy calcarenites. Above, the Bonifacio member is composed of coralline sandstones with limestone cement and of coralline sandy calcarenites. Many lens filled of gravel material are present. Well-cemented limestone completes the series (Reynaud et al., 2012).

\subsection{Hydrogeology background}

The hydrogeology includes two main aquifers separated by a silty layer within the Cala di Labra formation (Fig.2). The Miocene stratifications display also a slight dipping oriented NE-SW which may also influence the groundwater flow. Fracturing of surrounding granitic massifs is potentially favourable to an hydraulic connection with the carbonated plateau, but no evidence has been previously established. The geophysical survey also identified two aquifer levels : the upper aquifer, characterized by a hydraulic conductivity of $1.3 \times 10^{-4}$ to $2.5 \times 10^{-4} \mathrm{~m} / \mathrm{s}$ and the lower aquifer with a hydraulic conductivity of 1 to $5.0 \times 10^{-6} \mathrm{~m} / \mathrm{s}$ (Dörfliger et al., 2002). These values can be considered as favourable to groundwater flow. On the contrary, the silty level of the Cala di Labra formation presents an unfavourable aquifer potential, with a hydraulic conductivity estimated to less than $3 \times 10^{-7} \mathrm{~m} / \mathrm{s}$. Pumping tests showed more favourable values of $2.2 \times 10^{-6} \mathrm{~m} / \mathrm{s}$ at $\mathrm{B} 5,8.2 \times 10^{-6} \mathrm{~m} / \mathrm{s}$ for the upper aquifer 
and $1.7 \times 10^{-5} \mathrm{~m} / \mathrm{s}$ for the lower aquifer (Alamy and Chiari, 2010). The values for the silty level of Cala di labra are similar to the geophysical approach $\left(2.7 \times 10^{-7} \mathrm{~m} / \mathrm{s}\right)$.

A major hydrogeological characteristic of the aquifer is its thick unsaturated zone. The piezometric levels for the upper aquifer range from -0.97 to 21.75 masl (Table 1) and from 10.96 to 62.05 masl for the lower aquifer (some values can be influenced by pumping for exploited wells and boreholes). The lower aquifer can consequently be slightly artesian in some places but the differences in water levels between the upper and the lower aquifer are more in favour of a global downward vertical drainance. The morphology of the granite bedrock highlights the presence of channels which seems to favour the groundwater flow. Two main flow directions can be identified on the piezometric map: one direction is heading towards the Bonifacio harbour and the other one towards the Sant'Amanza bay.

\section{Method}

\subsection{Sampled wells and boreholes}

The use of atmospheric gases in the multi-tracing strategy has conditioned the selection of sampling points which allow pumping and sampling conditions with no atmospheric contact. A selection of 4 wells and 13 boreholes was sampled in May 2013 and in October 2013 (Fig.1 and Table 1) all over the study area. The screening interval of the wells and boreholes is 5 to $15 \mathrm{~m}$ and 44 to $269 \mathrm{~m}$ respectively. In this paper, groundwater from the upper aquifer and located in the recharge area $\left(\mathrm{UA}_{\mathrm{r}}\right)$ corresponds to B1, B2, B3 and B10; groundwater from the upper aquifer and located at the bottom of the valleys $\left(\mathrm{UA}_{\mathrm{v}}\right)$ and disposed along flow lines corresponds to $\mathrm{W} 1, \mathrm{~W} 2, \mathrm{~W} 3, \mathrm{~W} 4, \mathrm{~B} 4, \mathrm{~B} 5, \mathrm{~B} 6$ and B7. The lower aquifer (LA) is represented by B8, B9 and B11. Samples B12 and B13 characterize groundwater from the granites (G).

Sampling in the unexploited boreholes and wells was performed using a Grundfoss MP1 or a Comet submersible pump, depending on the sampling depth, both with a nylon tube. For exploited wells and boreholes, water was sampled directly at the tap avoiding any air contamination. For groundwater from the UAr and the UAv, water levels have been measured before pumping in order to establish the potentiometric map (Fig. 1).

\subsection{Sampling and analytical methods}

\subsubsection{Geochemistry}


Electrical Conductivity (EC), Temperature (T) and $\mathrm{pH}$ were measured in the field using a WTW Cond 3310 meter and a WTW pH 3310 meter. Alkalinity was determined in the field using a $\mathrm{HACH}$ digital titrator.

Samples for major ions $\left(\mathrm{Cl}^{-}, \mathrm{NO}_{3}^{-}, \mathrm{SO}_{4}{ }^{2-}, \mathrm{Na}^{+}, \mathrm{K}^{+}, \mathrm{Mg}^{2+}\right.$ and $\left.\mathrm{Ca}^{2+}\right)$ analysis were collected in two $50 \mathrm{~mL}$ polyethylene bottles after filtration through $0.45 \mu \mathrm{m}$ nitrocellulose membranes and stored at $4{ }^{\circ} \mathrm{C}$. One of them was acidified with ultrapure $\mathrm{HNO}_{3}$ for cation analysis. The concentrations were determined by ionic chromatography using a Dionex ICS 1100 chromatograph at the hydrogeology department of the University of Corsica, France. The quality of the chemical analysis was checked by calculating the ionic balance error. Analyses were rejected if the ionic balance error was greater than $5 \%$.

Samples for trace elements $\mathrm{Br}^{-}, \mathrm{Ba}^{2+}$ and $\mathrm{B}^{+}$were collected in $50 \mathrm{~mL}$ polyethylene bottles after filtration through $0.20 \mu \mathrm{m}$ nitrocellulose membranes and acidification using ultrapure $\mathrm{HNO}_{3}$ and then stored at $4^{\circ} \mathrm{C}$. Trace elements were analysed by Q-ICPMS X series II Thermo Fisher at the AETE technical platform of the University of Montpellier, France.

Samples for stable isotopes of the water molecule were collected in $20 \mathrm{~mL}$ amber glass bottles without head-space to guarantee a perfect conservation. Stable isotopes were measured using a liquid-water stable isotope analyser DLT-100 (Los Gatos Research) at the Hydrogeology Department of the University of Corsica, France, according to the analytical scheme recommended by the IAEA (Penna et al., 2010). The quality of the isotopic analysis was checked using a standard deviation condition up to $1 \%$ for $\delta^{2} \mathrm{H}$ and up to $0.1 \%$ for $\delta^{18} \mathrm{O}$.

For the determination of $\delta^{13} \mathrm{C}$ of the dissolved inorganic carbon (DIC), samples were collected in $500 \mathrm{~mL}$ polyethylene bottles with air-tight caps and preserved with $\mathrm{HgCl}_{2}$ to prevent biological activity after filtration through $0.45 \mu \mathrm{m}$ nitrocellulose membranes. Analyses were performed at the Hydrogeology Department of the University of Avignon, France, using mass spectrometry.

\subsubsection{Dating tracers, excess air and recharge temperature}

Sampling for ${ }^{3} \mathrm{H}$ analyses was carried out in $500 \mathrm{~mL}$ polyethylene bottles and analysis were performed at the hydrogeology Department of the University of Avignon, France, by electrolytic enrichment and liquid scintillation counting method (Thatcher et al., 1977).

Groundwater for CFCs and $\mathrm{SF}_{6}$ analyses was sampled in stainless-steel ampoules after washing through at least three volumes of the ampoule before closing it. No contact with air was allowed during sampling. Water for noble gases analyses was sampled in $500 \mathrm{~mL}$ glass 
bottles by over flushing. The bottles were submerged in flowing water, flushed, and capped without headspace.

Analyses were performed at the OSUR Geosciences Laboratory of the University of Rennes 1, France. CFCs and $\mathrm{SF}_{6}$ concentrations in groundwater were obtained by degassing water samples by $\mathrm{N}_{2}$ stripping. Gases were trapped in a stainless-steel tube filled with HayesepD and maintained at $-100^{\circ} \mathrm{C}$ in an ethanol bath. After $10 \mathrm{~min}$ of pre-concentration, the gases were injected into a Gas Chromatograph equipped with an Electron Capture Detector (GCECD) by immersing the trap into boiling water. The analytical uncertainty is estimated to be $1 \%$ to $3 \%$ for $\mathrm{CFCs}$ and near $5 \%$ for $\mathrm{SF}_{6}$. Thus, the global uncertainty on residence time, including sampling, analysis, selection of the recharge temperature in Henry's law, and dispersion-adsorption effects, is estimated to be from 2 to 11 a (Ayraud et al., 2008; Labasque et al., 2006; Labasque et al., 2014).

The concentrations of dissolved noble gases $\mathrm{Ne}, \mathrm{Ar}$ and $\mathrm{N}_{2}$ (Table 3) in groundwater are used to estimate recharge temperatures and the excess air (Mazor, 1979 ; Heaton and Vogel, 1981 ; Busenberg and Plummer, 1992). The recharge temperature is the temperature at the water table in the recharge zone at the time of separation from the atmosphere during recharge and the excess air is the quantity of air trapped during recharge and dissolved in groundwater. The unfractionated excess-air model using $\mathrm{N}_{2}$-Ar data may be considered to calculate these values, essential to determine the CFCs and $\mathrm{SF}_{6}$ solubility in groundwater (Aeschbach-Hertig et al., 1999; Aeschbach-Hertig et al., 2000; Plummer et al., 2012). In the Bonifacio aquifer this model was applied. The average recharge temperature obtained is around $17.4^{\circ} \mathrm{C}$, corresponding closely to the mean annual temperature in Bonifacio $\left(16.8^{\circ} \mathrm{C}\right)$. The excess air ranges from -1.53 to $6.66 \mathrm{~mL} / \mathrm{L}$. Monte Carlo simulation was performed to generate the range of the uncertainties of the model parameters. Uncertainty regarding the temperature is about $2^{\circ} \mathrm{C}$ and $1 \mathrm{~mL} / \mathrm{L}$ for the excess air volume. These uncertainties predicted by Monte Carlo simulation are high, but seem sufficiently similar to the temperatures measured in the field to be used to deduce, following the CFCs and $\mathrm{SF}_{6}$ solubility in groundwater, the corresponding atmospheric gas content of recharge year.

Noble gases are extracted by head-space extraction with a He phase (Ayraud et al., 2008; Labasque et al., 2006). Ar and $\mathrm{Ne}$ were subsequently measured using a micro-gas chromatograph (GC 3000, SRA instruments) at the OSUR Geosciences Laboratory of the University of Rennes 1, France. Uncertainties are around 3\% for Ne measurements and less than $2 \%$ for Ar. This analysis allows the Ne/Ar ratio to be assessed in order to compute an excess air contribution as well as recharge temperature. The calculations assume an average 
elevation for the samples of $100 \mathrm{~m} \mathrm{ASL}$. Excess air calculation is used to correct $\mathrm{SF}_{6}$ data, which could be greatly influenced by this parameter in contrast to CFCs (Ayraud et al., 2008; Maiss and Brenninkmeijer, 1998; Plummer et al., 2001).

The residence time corresponds to the groundwater transit time distribution in the saturated zone until the sampled point. In the modelling step, the residence times are calculated considering CFCs and $\mathrm{SF}_{6}$ as "perfect" tracers without exchange, contamination and/or degradation with their environment. In reality, these processes can occur and therefore may lead to a bias regarding residence times. Inter-comparison between the four residence times obtained with the 4 tracers highlights either a common residence time or a contamination or degradation effect influencing one or several tracers (Aeschbach-Hertig et al., 1998; Beyerle et al., 1999; Gooddy et al., 2006; Gourcy et al., 2009; Harnisch and Eisenhauer, 1998; Harnisch et al., 2000; Heaton and Vogel, 1981). For each sampled points, three models were tested to determine the residence times: the Piston Flow Model (PFM), the Exponential Model (EM) and the Binary Mixing Model (BMM), all being described in Małoszewski and Zuber (1982) and in Cook and Herczeg (2000). The PFM, EM and BMM modelling tests have been achieved with the USGS Excel Worksheets (http://water.usgs.gov/lab/software/tracer_model/) with the implementation of the atmospheric concentrations for 1940-2013 period. Models were selected on the basis of available geological, hydrogeological and hydrochemical information. In this study, only the BMM proved to be relevant. This model assumes a mixing between two main flow lines since infiltration into the saturated zone to the sampled point.

The BMM assumes a mixing occurring between an old end-member and a younger one. The groundwater weighted ages may be thus computed following the gas solubility governed by the Henry's law, by a weighted proportion between an old end-member $(100 \%$ of old groundwater corresponding to a given year) and a younger one (100\% of young groundwater corresponding to a more recent year) giving the best fitting of groundwater samples with the curves.

\section{Results}

\subsection{Field parameters and hydrochemistry}

Most groundwater temperatures are close to the mean annual air temperature in Bonifacio $\left(16.8^{\circ} \mathrm{C}\right)$.. Some samples display a higher temperature, up to $20.1^{\circ} \mathrm{C}$ (Table 2 ) in agreement with the atmospheric temperature during sampling, which took place in May 2013. Groundwater from the carbonate plateau shows a circum neutral $\mathrm{pH}$, between 6.7 and 7.3 
reflecting carbonate dissolution. Nevertheless, $\mathrm{pH}$ values about 6.7 are found in the granites. The electric conductivity (EC) ranges between 999 and $2090 \mu \mathrm{S} / \mathrm{cm}$ (Table 2). The lowest EC $(<1100 \mu \mathrm{S} / \mathrm{cm})$ are mainly observed in groundwater from the $\mathrm{UA}_{\mathrm{r}}$ and the LA whereas the highest EC $(>1900 \mu \mathrm{S} / \mathrm{cm})$ are mainly observed in some groundwater from the $\mathrm{UA}_{\mathrm{v}}$ and the $\mathrm{G}$. Intermediate EC (1100-1900 $\mu \mathrm{S} / \mathrm{cm})$ are measured in some groundwater from the $\mathrm{UA}_{\mathrm{v}}$.

Groundwater from the LA or the $\mathrm{UA}_{\mathrm{v}}$ displays generally the highest chloride and sodium concentrations (Table 2), giving a $\mathrm{Na}^{+}-\mathrm{Cl}^{-}$water type (Fig. 3). Furthermore, the plot of $\mathrm{Cl}^{-}$in relation with $\mathrm{Na}^{+}$and $\mathrm{Mg}^{2+}$ (Fig. 4a and 4b) are close to the seawater ratio and marked by correlation coefficients ( $\mathrm{r}$ ) higher than 0.90 , displaying a marine origin for these elements. The same trend is observed with $\mathrm{Br}^{-}, \mathrm{Ba}^{2+}$ and $\mathrm{B}^{+}$. For these elements, the highest values are observed for groundwater from the $\mathrm{G}$ or the $\mathrm{UA}_{\mathrm{v}}$. The plot of $\mathrm{Cl}^{-}$in relation with $\mathrm{Br}^{-}, \mathrm{Ba}^{2+}$ and $\mathrm{B}^{+}$(Fig. 4c, 4d and 4e) are marked by correlation coefficients (r) higher than 0.62 , suggesting also a marine origin for these elements and in particular for the $\mathrm{Br}^{-}$with a $\mathrm{Br}^{-} / \mathrm{Cl}^{-}$ratio equal to the seawater (Fig. 4c). The marine elements appear to be important in the high EC values of groundwater.

Groundwater from the $\mathrm{UA}_{\mathrm{r}}$ and from the $\mathrm{UA}_{\mathrm{v}}$ displays the highest calcium and bicarbonate concentrations (Table 2), giving a $\mathrm{Ca}^{2+}-\mathrm{HCO}_{3}{ }^{-}$water type (Fig. 3). Furthermore, the plot of $\mathrm{Ca}^{2+}$ vs $\mathrm{HCO}_{3}^{-}$is close to the calcite dissolution ratio and is marked by a correlation coefficient (r) around 0.63 , showing the influence of carbonate dissolution for these elements (Fig. 4f).

The $\mathrm{NO}_{3}{ }^{-}, \mathrm{K}^{+}$and $\mathrm{SO}_{4}{ }^{2-}$ give evidence of an anthropogenic fingerprint on groundwater. The natural nitrate concentration of groundwater in the absence of nitrogen fertilization is estimated between 5 and $7 \mathrm{mg} / \mathrm{L}$ (Appelo and Postma, 1999). However, concentrations found can reach $40 \mathrm{mg} / \mathrm{L}$ in some places (Table 2) which indicates that groundwater is impacted by human activities. Potassium in groundwater is generally linked with igneous rocks (orthoclase) or clay weathering. In this case, groundwater displays concentrations up to 10 $\mathrm{mg} / \mathrm{L}$ (Rail, 2000), as observed in Bonifacio groundwater. Furthermore, the $\mathrm{Cl}^{-} / \mathrm{SO}_{4}{ }^{2-}$ ratio is largely higher than seawater or anhydrite, suggesting an anthropogenic origin for $\mathrm{SO}_{4}{ }^{2}$ (Fig. $4 \mathrm{~g}$ and $4 \mathrm{~h})$.

The boreholes from $\mathrm{G}$ correspond to the only points which are not influenced by a carbonated mineralization. However some samples from the $\mathrm{UA}_{\mathrm{r}}$ and the $\mathrm{UA}_{\mathrm{v}}(\mathrm{B} 1, \mathrm{~B} 4$ and $\mathrm{W} 1)$ are also rather influenced by the marine signature. The most carbonated water type is observed for the $\mathrm{UA}_{\mathrm{r}}(\mathrm{B} 2)$. The hydrochemical data show a gradual evolution of the water types, from a $\mathrm{Ca}^{2+}$ $\mathrm{HCO}_{3}{ }^{-}$water type in the centre of the plateau to a $\mathrm{Na}^{+}-\mathrm{Cl}^{-}$water type near the shores (Fig.3). 


\section{2. $\mathrm{SiO}_{2}$ and ${ }^{13} \mathrm{C}$}

The lowest $\mathrm{SiO}_{2}$ concentrations in groundwater are found in the $\mathrm{UA}_{\mathrm{r}}$ and $\mathrm{UA}_{\mathrm{v}}$, whereas the highest concentrations are found in the LA and G. Some samples display concentrations different from what is expected in the granite e.g. B13 $(11.2 \mathrm{mg} / \mathrm{L})$, or in the carbonates W3 $(16.4 \mathrm{mg} / \mathrm{L})$, probably in relation with mixing processes.

The carbon-13 isotopic ratios range from -16.9 to $-10.7 \%$ (Table 2). The most enriched values correspond to groundwater from the LA or the $\mathrm{UA}_{\mathrm{v}}$ reflecting interaction with carbonate rocks whose ratio is around $0 \%$.

\subsection{Stable isotopes of the water molecule}

The isotopic composition of groundwater displays values between $-6.34 \%$ and $-4.79 \%$ for $\delta^{18} \mathrm{O}$ and between $-36.16 \%$ and $-29.82 \%$ for $\delta^{2} \mathrm{H}$ (Fig. 5). The samples plot between the Global Meteoric Water Line (GMWL) and the Western Mediterranean Meteoric Water Line (WMMWL), the latter being characterized by the following equation $\delta^{2} \mathrm{H}=8 \delta^{18} \mathrm{O}+14$ (Celle-Jeanton et al., 2001). The isotopic signal appears as relatively homogeneous within the aquifer. Excess deuterium is between 8.51 and $12.72 \%$ indicating no detectable evaporation, except for B9 which stable isotopic ratios indicate a probably slight evaporation or a little seawater intrusion trend (Table 2 ).

\subsection{Groundwater residence time}

\subsubsection{Tritium}

The ${ }^{3} \mathrm{H}$ concentrations range from 0 to $5.7 \mathrm{TU}$ (Table 3). Groundwater from the LA and the $\mathrm{UA}_{\mathrm{v}}$ (B5, W3, B6 and B7) displays the lowest concentrations, below 1-2 TU. All other groundwater samples displays detectable concentrations but lower than the current atmospheric content, between 7.5 and 8 TU in the Northern Hemisphere (Blavoux et al., 2013), highlighting an important mixing with post-1950's water.

\subsubsection{Residence time model}

CFCs and $\mathrm{SF}_{6}$ contents in groundwater are very contrasted ranging from 9 to $255 \mathrm{pptv}$ for CFC-11, 16 to 546 pptv for CFC-12, 4 to 160 pptv for CFC-113 and from 0.70 to 18.37 pptv for $\mathrm{SF}_{6}$ (Table 3). The higher values, corresponding to the actual atmospheric content, are mainly observed for groundwater from $\mathrm{UA}_{\mathrm{r}}$ and $\mathrm{UA}_{\mathrm{v}}$, whereas the lowest are observed for the 
LA. Samples from the granite display higher $\mathrm{SF}_{6}$ values than the one of the atmospheric chronicles, highlighting another origin for this component (Fig. 6).

The most coherent model for all the samples was the BMM. All the values plot on the same binary mixing line between an old end-member ( $>1950$ 's) and a young end-member of about 9 years old (Fig. 6), which was suggested by the tritium data (Table 3). A gradual evolution of mixing ratios (giving residence times) appears in the upper aquifer. For the $U_{\mathrm{r}}$ mixing ratios evolve from 85 to $95 \%$ of young water (B1 and B2), whereas along potentiometric lines of the $\mathrm{UA}_{\mathrm{v}}$ the ratio of young water is from $50-60 \%$ (B4 and B6) to finally $20 \%$ (W2 and W3) at the outlet near the Bonifacio harbour. The same pattern is observed for the Canali valley, where mixing ratios evolve from 90 to $45 \%$ of young water respectively for B10 $\left(\mathrm{UA}_{\mathrm{r}}\right)$ and $\mathrm{B} 7$ $\left(\mathrm{UA}_{\mathrm{v}}\right)$ in the outlet located in the Sant'Amanza bay. The ratio of young water is between 40 to $65 \%$ in the $\mathrm{G}$, and between 5 to $25 \%$ in the LA.

Even if determining mixing ratios gives lot of interesting information, it is also necessary to quantify the groundwater residence times to better understand the aquifer functioning. In so far as all groundwater samples display detectable concentrations in $\mathrm{CFCs}_{\text {and }} \mathrm{SF}_{6}$, no sample is supposed to be older than the dating method scale. The groundwater residence times have been thus calculated (Table 4$)$ by a weighted proportion between an old end-member $(100 \%$ of old groundwater corresponding to the year 1940, last year without detectable tracer concentrations in the atmosphere) and a younger one about 9 a (100\% of young groundwater corresponding to the year 2004, giving the best fitting of groundwater samples with the curves). Groundwater from the LA and the $\mathrm{UA}_{\mathrm{v}}$ are the oldest with weighted residence times between 50 and 60 a (W2, W3, B5, B8 and B9). The oldest groundwaters are located in the lower aquifer. Conversely, groundwater from the $\mathrm{UA}_{\mathrm{r}}$ is the youngest one with weighted residence times between 9 and 20 a (W1, B1, B2 and B10). Intermediate weighted residence times are obtained for the other samples from $\mathrm{UA}_{\mathrm{v}}$ and $\mathrm{G}$ with weighted residence times between 20 and 50 a (W4, B3, B4, B6, B7, B12 and B13).

\section{Discussion}

\subsection{Groundwater origin}

The very close isotopic signature of each groundwater sample suggests a same origin for all the groundwater regardless of their spatial distribution. The isotopic signature of groundwater is in good agreement with the isotopic signature of Piombino rainwater (-6.04 for $\delta^{18} \mathrm{O}$ and 36.6 for $\left.\delta^{2} \mathrm{H}\right)$ and Sassari rainwater $\left(-6.58\right.$ for $\delta^{18} \mathrm{O}$ and -37.3 for $\left.\delta^{2} \mathrm{H}\right)$ which are the closest 
Italian neighbouring rain stations (Longinelli and Selmo, 2003). The isotopic composition of groundwater is clearly different from the sea water composition analysed in the Strait of Bonifacio (1.07 for $\delta^{18} \mathrm{O}$ and 4.78 for $\delta^{2} \mathrm{H}$ ). The $\mathrm{Cl}^{-}$and $\mathrm{Na}^{+}$concentrations and the high EC of the groundwater is more in agreement with a coastal situation influenced by the seas sprays as for Spanish and Portuguese coastal aquifers (Alcala and Custodio, 2008; Cruz et al., 2011) and many others Mediterranean coastal aquifers (Bouzourra et al., 2015; Dazy et al., 1997; Ghabayen et al., 2006; Manca et al., 2015).

\subsection{Groundwater flow paths}

In order to bring out flow paths within the aquifer, potentiometric heads will be compared with the spatial evolution of groundwater hydrochemistry and weighted residence times. The BMM applied in this paper is usually appropriate for multi-layers aquifers (La Salle et al., 2012; Stuart et al., 2010). This model reveals the presence of "young" and "old" water bodies, in agreement with groundwater temperatures and only slightly influenced by the seasonal surface atmospheric conditions and by the tritium concentrations below 1-2 TU linked to an important ratio of pre-1950's water. Indeed, the correlation between the tritium and the groundwater weighted residence times are well correlated (Fig. 7a) with the lowest tritium concentrations and the longest residence times observed for the LA whereas the highest tritium concentrations and the shortest residence times are observed for the $\mathrm{UA}_{\mathrm{r}}$ and $\mathrm{UA}_{\mathrm{v}}$.

At Bonifacio, the coastal and extremely windy context seems to contribute to a concentration of chloride, sodium and other marine elements during crystallisation of sea sprays as observed on stone surface in a Greek coastal environment (Chabas et al., 2000). In this case, a salinization can appear during the aquifer recharge, the $\mathrm{Na}^{+}-\mathrm{Cl}^{-}$water type being more marked for groundwater infiltrated in recharge areas close to the coasts. Chemical elements associated to sea sprays hence constitutes good tracers of the recharge area, and thus of the ratio of young water. Indeed, The $\mathrm{Na}^{+}+\mathrm{Cl}^{-}, \mathrm{Br}^{-}, \mathrm{B}^{+}, \mathrm{Ba}^{2+}$ and $\mathrm{Mg}^{2+}$ versus ratio of young water graphs (Fig. $7 \mathrm{~b}$ to $7 \mathrm{f}$ ) show correlation coefficients ranging from 0.61 to 0.95 . For these elements, the higher the ratio of young water, the greater their concentration is, which validates the mixing ratios established. The younger groundwater are found in the UAr whereas in the $\mathrm{UA}_{\mathrm{v}}$, weighted residence time increases downstream and reaches 52 a at the outlet of the St. Julien valley. Same observation were made in the Canali valley where weighted ages reaches 39 a. The spatial distribution of residence times displays an aging along these two main flow lines according to the potentiometric heads identified in the hydrogeology background section $(\mathrm{Cf}$. 2.4.). 
Hydrolysis of silicate minerals is a slow process and the resulting changes in water chemistry are gradual (but less developed in carbonate aquifers) and reflects, as carbon-13, a qualitative aging of groundwater. Consequently, $\mathrm{SiO}_{2}$ and ${ }^{13} \mathrm{C}$ values in groundwater are linked to the intensity of water-rocks interactions, and are supposed to increase along the flow lines with the residence time. The $\mathrm{pH}$ values and chemical elements such as $\mathrm{Ca}^{2+}, \mathrm{HCO}_{3}{ }^{-}, \mathrm{SiO}_{2}$ and ${ }^{13} \mathrm{C}$ hence constitutes good indicators of water-rock interactions, and thus of the ratio of old water. The $\mathrm{Ca}^{2+}+\mathrm{HCO}_{3}^{-}$and $\mathrm{SiO}_{2}$ versus part of young water graphs (Fig. $7 \mathrm{~g}$ and $7 \mathrm{~h}$ ) displays inverse correlation coefficients ranging from 0.57 to 0.79 . For these elements, the lower the ratio of young water, the greater their concentration is. This is confirmed by the ${ }^{13} \mathrm{C}$ which values from -16.9 to $-10.7 \%$ indicates variable intensity of water-rock interaction processes. Indeed, the ${ }^{13} \mathrm{C}$ versus part of young water which shows an inverse correlation coefficient of about 0.77 (Fig. 7i), which argue in favour of the mixing ratios established. A groundwater aging takes place from the $G$ to the LA, suggesting a hydraulic connection between the $G$ and the LA.

Finally, the gradual groundwater aging observed from the upper aquifer to the bottom of the valleys and to the lower aquifer is in agreement with the potentiometric data displaying higher levels in the upper aquifer than in the lower aquifer (Fig.2 and Table 1). A probable downward vertical drainance from the upper to the lower aquifer is thus evidenced but seems however limited regarding the relatively low EC in the lower aquifer compared to the upper aquifer.

\subsection{Limits of the dating method}

The BMM gave groundwater weighted residence times between 9 and 60 a. This information reveals the presence of an inertial water body, as suggested by the tritium data. Probably, the old end-member may be underestimated because in limits of this dating method. Unfortunately, the Bonifacio aquifer location is too far from any survey station for atmospheric tritium to be used as a quantitative tracer to specify residence times, but the good correlation observed between the tritium concentrations and the ratios of young groundwater (Fig. 7a) indicates that tritium is yet a good qualitative indicator of residence time in this aquifer.

The weighted residence times are based on the equilibrium between CFC in atmospheric air and infiltrating water at the time of recharge. With increasing thickness of the UZ, gas 
transport processes play a larger role in the interpretation of CFC residence times due to sorption to solid phase particles and potential microbial degradation (Cook et al., 1995). Lag times may be observed and are mostly dependant on gas solubility, diffusion coefficients and soil water content (Cook and Herczeg, 2000; Heaton and Vogel, 1981) and geology (Cook et al., 1995; Cook et al., 2006). In addition, contamination problems may occur in presence of individual sewage treatment plants and tips (Archbold et al., 2012; Hohener et al., 2003) or gardening activities (Busenberg and Plummer, 2000; Spurlock et al., 2000). Within the Bonifacio aquifer, the presence of a thick UZ (with variable thickness, see Table 1) as well as the presence of some individual sewage treatment plants and gardening activities may probably modify groundwater residence time in some places. Groundwater weighted residence times obtained from the BMM may thus lose precision, but their spatial distribution stays consistent with an aging process in agreement with the flow lines organization deduced from the potentiometric map (Fig. 1).

\subsection{Tracing groundwater origins using $\mathrm{SF}_{6}$}

Weighted residence times have been deduced from anthropogenic atmospheric gases and validated using hydrochemical data. Nevertheless, $\mathrm{CFCs}$ or $\mathrm{SF}_{6}$ concentrations can sometimes lead to different residence time for a same sample, indicating that a tracer may not be conservative. Indeed, within the Bonifacio aquifer, groundwater from the LA and the G displays $\mathrm{SF}_{6}$ contents largely higher than those resulting from atmospheric chronicles. The high $\mathrm{SF}_{6}$ values are probably due to the presence of pegmatite veins in the surrounding fractured granites, source of terrigenous $\mathrm{SF}_{6}$ (Deeds et al., 2008; Friedrich et al., 2013; Harnisch and Eisenhauer, 1998). Terrigenic $\mathrm{SF}_{6}$ can thus affect the groundwater dating (Koh et al., 2007). As no $\mathrm{SF}_{6}$ source is likely in the lower aquifer, groundwater flow from the granite to the lower aquifer is suspected in particular since a gradual increase in residence time from the granites to the lower aquifer has been highlighted (Cf. 5.2.). This kind of problem is current but, thanks to the multi-tracer approach, is not restrictive for interpretations as it may help to characterize geochemical or biogeochemical processes. As an example, poor agreement between ${ }^{3} \mathrm{H}$ ages and CFC-11 and CFC-12 ages suggests that CFCs may not be conservative tracers in the Everglades (Happell et al., 2003). ${ }^{3} \mathrm{H} /{ }^{3} \mathrm{He}$ ages were used to calculate the expected concentration of CFC-11 and CFC-12 in groundwater. In the Bonifacio case, the expected $\mathrm{SF}_{6}$ contents with respect to the solubility of gas in water compatible with atmospheric chronicles have been calculated, and the offsets compared with the mixing line (Fig. 6) are reported in pptv in Table 4. Groundwater from the $\mathrm{G}$ displays the highest $\mathrm{SF}_{6}$ 
excess, up to 18.37 pptv. $\mathrm{SF}_{6}$ excess is also well marked in the LA, with values up to 7.05 pptv. Conversely, $\mathrm{SF}_{6}$ excess in the $\mathrm{UA}_{\mathrm{r}}$ and the $\mathrm{UA}_{\mathrm{v}}$ are relatively low, from 0 to $4.28 \mathrm{pptv}$ and 0 to 6.98 pptv respectively. These results consequently validate the hypothesis of an hydraulic connection between the surrounding granites and the sedimentary formations, with a major contribution in the lower aquifer and a minor one in the upper aquifer.

\subsection{Aquifer hydraulic conductivity estimations and residence time validation}

Hydraulic conductivity is a variable which describes the ability of a porous medium to allow fluid drainance. It has the dimension of a velocity $(\mathrm{m} / \mathrm{s})$, making it dependent on a time factor. In order to substantiate the groundwater residence times obtained in this study, it is thus interesting to compare the hydraulic conductivity values provided by the geophysical approach (Dörfliger et al., 2002) with values from a calculation incorporating the groundwater residence times from this paper. The calculation is performed considering the time difference a water parcel needs to travel between two sampling points (Suckow, 2014; Torgersen et al., 2013). For the LA, the calculation performed between B11 and B8 gives a value about $2.110^{-}$ ${ }^{6} \mathrm{~m} / \mathrm{s}$, slightly lower than the geophysics estimations. This is the same for the flow taking place between $B 12$ and $B 9$, from the $G$ to the $L A$, which gives a value of $4.910^{-6} \mathrm{~m} / \mathrm{s}$ (Cf. Hydrogeology section).. For the $\mathrm{UA}_{\mathrm{v}}$ and $\mathrm{UA}_{\mathrm{r}}$, the calculation has been applied on each flow line identified. The flow taking place between B10 and B7 in direction of the Sant'Amanza bay gives a value of $2.210^{-6} \mathrm{~m} / \mathrm{s}$, and the one between $\mathrm{B} 1$ and $\mathrm{W} 3$ in direction of the Bonifacio Harbour gives a value of $1.410^{-6} \mathrm{~m} / \mathrm{s}$. This is in very good agreement with the estimations obtained using geophysics, arguing in favour of the groundwater residence times established.

\subsection{Definition of a conceptual model of flow}

A description of the aquifer functioning in terms of groundwater mineralization, origins, flow paths and mixings can now be established highlighting the relevance of such approach for complex hydrosystems. A conceptual model of the Bonifacio plateau hydrosystem is thus proposed in Fig. 8 and comprises:

- An autochthonous recharge of the $\mathrm{UA}_{\mathrm{r}}$, provided by the input of rainwater with a lag time about 9 a due to the UZ. The groundwater weighted age increases from the $U_{\mathrm{r}}$ to the $\mathrm{UA}_{\mathrm{v}}$. Two outlets in agreement with the potentiometric heads are highlighted The weighted ages implies a multi-annual renewal rate of groundwater. 
- An allochthonous recharge provided by the fractured surrounding granites of the LA. The $\mathrm{SF}_{6}$ excesses due to the pegmatite veins have been quantified as very important in the LA and are probably related to a hydraulic connection with the granitic basement. Hence the aquifer system of the Bonifacio plateau must be extended out of its carbonate limits and also include the neighbouring granites. The weighted ages implies a multi-decadal renewal rate of groundwater.

- A slight autochthonous recharge from the UA to the LA by a downward hydraulic connection between these two levels as suggested by the potentiometric levels.

The results of this study imply to take into account the role of the fractured granitic bedrock in the functioning of the aquifer, from a quantitative and a qualitative point of view. Water-rock interactions need to be detailed in order to improve the end-members definition and the flow pattern (Bullen et al., 1996; Dogramaci and Herczeg, 2002; Gassama et al., 2012), as well as the impact of the sea sprays on the groundwater EC during the aquifer recharge (Alcalá and Custodio, 2008; Dazy et al., 1997).

Indeed, even if saltwater intrusion is a common problem for coastal aquifers (Chandrasekar et al., 2014; Han et al., 2014), and moreover in Mediterranean context (Petalas and Lambrakis, 2006; Sivan et al., 2005), no seawater intrusion is detected yet and the aquifer seems to be still protected from over abstraction despite an ever increasing pressure. It is nevertheless necessary to identify and quantify the different components of the local water balance to accurately evaluate the potential of the aquifer as a sustainable water resource in a semi-arid context.

\section{Conclusions}

The present study brings out interesting non-conventional implications for groundwater management in coastal areas. This first approach using hydrochemistry, isotopes and dating tools highlighted a preserved functioning of this hydrosystem in spite of the tourism development and the increase in private and public drinking water supply demand. This seems to be related with the fact that, even if the Bonifacio aquifer faces a low recharge linked to the semi-arid context, the granitic surroundings contribute to its recharge by raising the recharge area surface which is then extended to the whole surface catchment. However, this natural additional recharge of the aquifer needs to be quantified and the different components of the local water balance too, principally through the characterisation of the input signal and the quantification of the submarine groundwater discharge. All of these conclusions will help promoting the establishment of a proactive management strategy for the Bonifacio aquifer, 
principally taking into account the pluriannual to multi-decadal rate of renewal of groundwater as put in evidence in this paper. This initiative being in clear opposition with the widespread curative managements operating in many coastal aquifers in the Mediterranean, allowing to maintain (and not restore) a good quality and quantity of groundwater resources as advocated by the European Water Framework Directive (2000/60/EC).

From a theoretical point of view, this study also permitted to test the groundwater dating tools potential. Indeed, despite the complexity in the interpretation of the anthropogenic atmospheric gases $\mathrm{CFCs}$ and $\mathrm{SF}_{6}$ due to the unsaturated zone and the hydraulic connection with granites, relevant information on the global aquifer functioning were gained, illustrating the value of the multi tracer approach. The punctual multitracing experiment, coupled with CFCs and $\mathrm{SF}_{6}$, gave important information on groundwater mineralization processes and weighted residence times within this carbonate coastal aquifer with low prior knowledge, confirming the relevant use of this strategy as a primary investigative tool in this kind of system. The spatial evolution of apparent ages also allowed highlighting the flow conditions within the aquifer. The flow patterns were then confirmed based on the hydrogeological processes taking place during aquifer recharge or during groundwater aging along the flow lines. Isotopic $\left({ }^{3} \mathrm{H},{ }^{18} \mathrm{O},{ }^{2} \mathrm{H}\right.$ and ${ }^{13} \mathrm{C}$ ) and geochemical tracers (major ions, $\mathrm{Br}^{-}, \mathrm{Ba}^{+}$and $\mathrm{Sr}^{2+}$ ) were very relevant for this step. Linking residence time and hydrochemical evolution along flow path may consequently constitute an effective tool to better constrain the definition of complex hydrogeological conceptual models. Unlike most studies, terrigenic $\mathrm{SF}_{6}$ from granite formations were not a limiting factor in this paper. The quantification of $\mathrm{SF}_{6}$ excess permit to identify a lateral groundwater flow from the surrounding fractured granites towards the lower part of the aquifer mainly. The $\mathrm{SF}_{6}$ then proved to be a direct tracer of groundwater origin.

\section{Acknowledgment}

The Ph.D grant of Sébastien Santoni was financially supported by the regional council of Corsica (Collectivité Territoriale de Corse). The authors would like to thank the municipality of Bonifacio for their support and contribution to the implementation of the project. We greatly appreciated help from our colleague Eliot Chatton (OSUR Geosciences Laboratory of the University of Rennes 1, France) for his contribution in the calculation of dissolved-gas recharge temperatures and excess air. The authors would also like to thank the Bonifacio inhabitants for access to their wells and boreholes during the field sampling. 


\section{Reference}

Aeschbach-Hertig, W., Peeters, F., Beyerle, U., Kipfer, R., 1999. Interpretation of dissolved atmospheric noble gases in natural waters. Water Resources Research, 35: 2779-2792. DOI:10.1029/1999WR900130

Aeschbach-Hertig, W., Peeters, F., Beyerle, U., Kipfer, R., 2000. Palaeotemperature reconstruction from noble gases in ground water taking into account equilibration with entrapped air. Nature, 405: 1040-1044. DOI:10.1038/35016542

Aeschbach-Hertig, W., Schlosser, P., Stute, M., Simpson, H.J., Ludin, A., Clark, J.F., 1998. A H3/He-3 study of ground water flow in a fractured bedrock aquifer. Ground Water, 36: 661-670. DOI:10.1111/j.1745-6584.1998.tb02841.x

Alamy, Z., Chiari, J.-T., 2010. Renforcement des ressources en eau de la commune de Bonifacio Forages de recherche d'eau pour l'alimentation en eau potable de la commune - Dossier de fin de travaux. 136.

Alcala, F.J., Custodio, E., 2008. Atmospheric chloride deposition in continental Spain. Hydrological Processes, 22: 3636-3650. DOI:10.1002/hyp.6965

Alcalá, F.J., Custodio, E., 2008. Using the $\mathrm{Cl} / \mathrm{Br}$ ratio as a tracer to identify the origin of salinity in aquifers in Spain and Portugal. Journal of Hydrology, 359: 189-207.

DOI:10.1016/j.jhydrol.2008.06.028

Alvarado, J.A.C., Purtschert, R., Hinsby, K., Troldborg, L., Hofer, M., Kipfer, R., Aeschbach-Hertig, W., Arno-Synal, H., 2005. 36Cl in modern groundwater dated by a multi-tracer approach $(3 \mathrm{H} / 3 \mathrm{He}, \mathrm{SF} 6, \mathrm{CFC}-12$ and $85 \mathrm{Kr}):$ a case study in quaternary sand aquifers in the Odense Pilot River Basin, Denmark. Applied Geochemistry, 20: 599-609.

DOI:10.1016/j.apgeochem.2004.09.018

Anders, R., Mendez, G.O., Futa, K., Danskin, W.R., 2014. A Geochemical Approach to Determine Sources and Movement of Saline Groundwater in a Coastal Aquifer. Groundwater, 52: 756768. DOI:10.1111/gwat.12108

Appelo, C.A.J., Postma, D., 1999. Geochemistry, groundwater and pollution. Balkema, Rotterdam; Brookfield, VT.

Aquilina, L., de Dreuzy, J.-R., Gooddy, D., 2014. Dissolved gases in groundwater and groundwater dating methods: How useful for hydrogeological modeling? - Foreword to the special issue Preface. Applied Geochemistry, 50: 115-117. DOI:10.1016/j.apgeochem.2014.07.011

Archbold, M.E., Elliot, T., Kalin, R.M., 2012. Carbon Isotopic Fractionation of CFCs during Abiotic and Biotic Degradation. Environmental Science \& Technology, 46: 1764-1773. DOI:10.1021/es203386a

Ayraud, V., Aquilina, L., Labasque, T., Pauwels, H., Molenat, J., Pierson-Wickmann, A.-C., Durand, V., Bour, O., Tarits, C., Le Corre, P., Fourre, E., Merot, P., Davy, P., 2008.

Compartmentalization of physical and chemical properties in hard-rock aquifers deduced from chemical and groundwater age analyses. Applied Geochemistry, 23: 2686-2707. DOI:10.1016/j.apgeochem.2008.06.001

Baudron, P., Barbecot, F., Garcia Arostegui, J.L., Leduc, C., Travi, Y., Martinez-Vicente, D., 2014. Impacts of human activities on recharge in a multilayered semiarid aquifer (Campo de Cartagena, SE Spain). Hydrological Processes, 28: 2223-2236. DOI:10.1002/hyp.9771

Bertrand, G., Celle-Jeanton, H., Huneau, F., Loock, S., Renac, C., 2010. Identification of different groundwater flowpaths within volcanic aquifers using natural tracers for the evaluation of the influence of lava flows morphology (Argnat basin, Chaine des Puys, France). Journal of Hydrology, 391: 223-234. DOI:10.1016/j.jhydrol.2010.07.021

Bethke, C.M., Johnson, T.M., 2008. Groundwater age and groundwater age dating, Annual Review of Earth and Planetary Sciences. Annual Reviews, Palo Alto, pp. 121-152.

Beyerle, U., Aeschbach-Hertig, W., Hofer, M., Imboden, D.M., Baur, H., Kipfer, R., 1999. Infiltration of river water to a shallow aquifer investigated with $\mathrm{H}-3 / \mathrm{He}-3$, noble gases and CFCs. Journal of Hydrology, 220: 169-185. DOI:10.1016/S0022-1694(99)00069-4

Blavoux, B., Lachassagne, P., Henriot, A., Ladouche, B., Marc, V., Beley, J.-J., Nicoud, G., Olive, P., 2013. A fifty-year chronicle of tritium data for characterising the functioning of the Evian and 
Thonon (France) glacial aquifers. Journal of Hydrology, 494: 116-133.

DOI:10.1016/j.jhydrol.2013.04.029

Bouzourra, H., Bouhlila, R., Elango, L., Slama, F., Ouslati, N., 2015. Characterizaton of mechanisms and processes of groundwater salinization in irrigated coastal area using statistics, GIS, and hydrogeochemical investigations. Environmental Science and Pollution Research, 22: 2643 2660. DOI:10.1007/s11356-014-3428-0

Bullen, T.D., Krabbenhoft, D.P., Kendall, C., 1996. Kinetic and mineralogic controls on the evolution of groundwater chemistry and $\mathrm{Sr}-87 / \mathrm{Sr}-86$ in a sandy silicate aquifer, northern Wisconsin, USA. Geochimica Et Cosmochimica Acta, 60: 1807-1821. DOI:10.1016/00167037(96)00052-X

Busenberg, E., Plummer, L., 1992. Use of Chlorofluorocarbons (ccl3f and Ccl2f2) as Hydrologic Tracers and Age-Dating Tools - the Alluvium and Terrace System of Central Oklahoma. Water Resources Research, 28: 2257-2283. DOI:10.1029/92WR01263

Busenberg, E., Plummer, L.N., 2000. Dating young groundwater with sulfur hexafluoride: Natural and anthropogenic sources of sulfur hexafluoride. Water Resources Research, 36: 3011-3030. DOI:10.1029/2000WR900151

Celle-Jeanton, H., Travi, Y., Blavoux, B., 2001. Isotopic typology of the precipitation in the Western Mediterranean Region at three different time scales. Geophysical Research Letters, 28(7): 1215-1218. DOI:10.1029/2000gl012407

Chabas, A., Jeannette, D., Lefevre, R.A., 2000. Crystallization and dissolution of airborne sea-salts on weathered marble in a coastal environment at Delos (Cyclades-Greece). Atmospheric Environment, 34: 219-224. DOI:10.1016/S1352-2310(99)00256-3

Chandrasekar, N., Selvakumar, S., Srinivas, Y., Wilson, J.S.J., Peter, T.S., Magesh, N.S., 2014. Hydrogeochemical assessment of groundwater quality along the coastal aquifers of southern Tamil Nadu, India. Environmental Earth Sciences, 71: 4739-4750. DOI:10.1007/s12665-0132864-3

Cook, P., Solomon, D., Plummer, L., Busenberg, E., Schiff, S., 1995. Chlorofluorocarbons as Tracers of Groundwater Transport Processes in a Shallow, Silty Sand Aquifer. Water Resources Research, 31: 425-434. DOI:10.1029/94WR02528

Cook, P.G., Herczeg, A.L., 2000. Environmental tracers in subsurface hydrology. Springer Science \& Business Media.

Cook, P.G., Plummer, L.N., Busenberg, E., Solomon, D.K., Han, L.F., 2006. Chapter 4 : Effects and processes that can modify apparent CFC age. Use of chlorofluorocarbons in hydrology : a guidebook. - Vienna : International Atomic Agency, STI/PUB/1238. ISBN 92-0-1000805-8.

Cook, P.G., Solomon, D.K., 1997. Recent advances in dating young groundwater: Chlorofluorocarbons, H-3/He-3 and Kr-85. Journal of Hydrology, 191: 245-265. DOI:10.1016/S0022-1694(96)03051-X

Corcho Alvarado, J.A., Purtschert, R., Barbecot, F., Chabault, C., Rueedi, J., Schneider, V., Aeschbach-Hertig, W., Kipfer, R., Loosli, H.H., 2007. Constraining the age distribution of highly mixed groundwater using 39Ar: A multiple environmental tracer $(3 \mathrm{H} / 3 \mathrm{He}, 85 \mathrm{Kr}, 39 \mathrm{Ar}$, and 14C) study in the semiconfined Fontainebleau Sands Aquifer (France). Water Resources Research, 43: W03427. DOI:10.1029/2006WR005096

Cruz, J.V., Coutinho, R., Pacheco, D., Cymbron, R., Antunes, P., Freire, P., Mendes, S., 2011. Groundwater salinization in the Azores archipelago (Portugal). Environmental Earth Sciences, 62: 1273-1285. DOI:10.1007/s12665-010-0615-2

Dazy, J., Drogue, C., Charmanidis, P., Darlet, C., 1997. The influence of marine inflows on the chemical composition of groundwater in small islands: The example of the Cyclades (Greece). Environmental Geology, 31: 133-141.

Deeds, D.A., Vollmer, M.K., Kulongoski, J.T., Miller, B.R., Muhle, J., Harth, C.M., Izbicki, J.A., Hilton, D.R., Weiss, R.F., 2008. Evidence for crustal degassing of CF4 and SF6 in Mojave Desert groundwaters. Geochimica Et Cosmochimica Acta, 72: 999-1013. DOI:10.1016/j.gca.2007.11.027

Deino, A., Gattacceca, J., Rizzo, R., Montanari, A., 2001. Ar-40/Ar-39 dating and paleomagnetism of the Miocene volcanic succession of Monte Furru (western Sardinia): Implications for the 
rotation history of the Corsica-Sardinia microplate. Geophysical Research Letters, 28: 3373 3376. DOI:10.1029/2001GL012941

Delbart, C., Barbecot, F., Valdes, D., Tognelli, A., Fourre, E., Purtschert, R., Couchoux, L., JeanBaptiste, P., 2014. Investigation of young water inflow in karst aquifers using SF6-CFC$3 \mathrm{H} / \mathrm{He}-85 \mathrm{Kr}-39 \mathrm{Ar}$ and stable isotope components. Applied Geochemistry, 50: 164-176. DOI:10.1016/j.apgeochem.2014.01.011

Dogramaci, S.S., Herczeg, A.L., 2002. Strontium and carbon isotope constraints on carbonate-solution interactions and inter-aquifer mixing in groundwaters of the semi-arid Murray Basin, Australia. Journal of Hydrology, 262: 50-67. DOI:10.1016/S0022-1694(02)00021-5

Dörfliger, N., Ferrandini, J., Ferrandini, M., Mathieu, F., 2002. Caractérisation géométrique et hydrodynamique du causse de Bonifacio (Corse) à partir d'une synthèse des connaissances géologiques et hydrogéologiques et par méthodes géophysiques., BRGM/RP-51860-FR. DOI:BRGM/RP-51860-FR

Ferrandini, J., Gattacceca, J., Ferrandini, M., Deino, A., Janin, M.-C., 2003. Chronostratigraphy and paleomagnetism of Oligo-Miocene deposits of Corsica (France) : geodynamic implications for the liguro-provençal basin spreading. Bulletin de la Societe Geologique de France, 174: 357371. DOI:10.2113/174.4.357

Friedrich, R., Vero, G., von Rohden, C., Lessmann, B., Kipfer, R., Aeschbach-Hertig, W., 2013. Factors controlling terrigenic SF6 in young groundwater of the Odenwald region (Germany). Applied Geochemistry, 33: 318-329. DOI:10.1016/j.apgeochem.2013.03.002

Gassama, N., Kasper, H.U., Dia, A., Cocirta, C., Bouhnik-LeCoz, M., 2012. Discrimination between different water bodies from a multilayered aquifer (Kaluvelly watershed, India): Trace element signature. Applied Geochemistry, 27: 715-728. DOI:10.1016/j.apgeochem.2011.12.001

Gattacceca, J., Deino, A., Rizzo, R., Jones, D.S., Henry, B., Beaudoin, B., Vadeboin, F., 2007. Miocene rotation of Sardinia: New paleomagnetic and geochronological constraints and geodynamic implications. Earth and Planetary Science Letters, 258: 359-377. DOI:10.1016/j.eps1.2007.02.003

Ghabayen, S.M.S., McKee, M., Kemblowski, M., 2006. Ionic and isotopic ratios for identification of salinity sources and missing data in the Gaza aquifer. Journal of Hydrology, 318: 360-373. DOI:10.1016/j.jhydrol.2005.06.041

Ghiglieri, G., Carletti, A., Pittalis, D., 2014. Runoff coefficient and average yearly natural aquifer recharge assessment by physiography-based indirect methods for the island of Sardinia (Italy) and its NW area (Nurra). Journal of Hydrology, 519: 1779-1791. DOI:10.1016/j.jhydrol.2014.09.054

Gilmore, T.E., Genereux, D.P., Solomon, D.K., Solder, J.E., 2016. Groundwater transit time distribution and mean from streambed sampling in an agricultural coastal plain watershed, North Carolina, USA. Water Resources Research.

Gooddy, D.C., Darling, W.G., Abesser, C., Lapworth, D.J., 2006. Using chlorofluorocarbons (CFCs) and sulphur hexafluoride (SF6) to characterise groundwater movement and residence time in a lowland Chalk catchment. Journal of Hydrology, 330: 44-52.

DOI:10.1016/j.jhydrol.2006.04.011

Goode, D.J., 1996. Direct simulation of groundwater age. Water Resources Research, 32: 289-296. DOI:10.1029/95WR03401

Gourcy, L., Baran, N., Vittecoq, B., 2009. Improving the knowledge of pesticide and nitrate transfer processes using age-dating tools (CFC, SF6, H-3) in a volcanic island (Martinique, French West Indies). Journal of Contaminant Hydrology, 108: 107-117. DOI:10.1016/j.jconhyd.2009.06.004

Han, D.M., Song, X.F., Currell, M.J., Yang, J.L., Xiao, G.Q., 2014. Chemical and isotopic constraints on evolution of groundwater salinization in the coastal plain aquifer of Laizhou Bay, China. Journal of Hydrology, 508: 12-27. DOI:10.1016/j.jhydrol.2013.10.040

Happell, J.D., Price, R.M., Top, Z., Swart, P.K., 2003. Evidence for the removal of CFC-11, CFC-12, and CFC-113 at the groundwater-surface water interface in the Everglades. Journal of Hydrology, 279: 94-105. DOI:10.1016/S0022-1694(03)00169-0 
Harnisch, J., Eisenhauer, A., 1998. Natural CF4 and SF6 on Earth. Geophysical Research Letters, 25: 2401-2404. DOI:10.1029/98GL01779

Harnisch, J., Frische, M., Borchers, R., Eisenhauer, A., Jordan, A., 2000. Natural fluorinated organics in fluorite and rocks. Geophysical Research Letters, 27: 1883-1886.

DOI:10.1029/2000GL008488

Heaton, T., Vogel, J., 1981. Excess Air in Groundwater. Journal of Hydrology, 50: 201-216. DOI:10.1016/0022-1694(81)90070-6

Hohener, P., Werner, D., Balsiger, C., Pasteris, G., 2003. Worldwide occurrence and fate of chlorofluorocarbons in groundwater. Critical Reviews in Environmental Science and Technology, 33: 1-29. DOI:10.1080/10643380390814433

Jaunat, J., Huneau, F., Dupuy, A., Celle-Jeanton, H., Vergnaud-Ayraud, V., Aquilina, L., Labasque, T., Le Coustumer, P., 2012. Hydrochemical data and groundwater dating to infer differential flowpaths through weathered profiles of a fractured aquifer. Applied Geochemistry, 27: 20532067. DOI:10.1016/j.apgeochem.2012.06.009

Jodar, J., Javier Lamban, L., Medina, A., Custodio, E., 2014. Exact analytical solution of the convolution integral for classical hydrogeological lumped-parameter models and typical input tracer functions in natural gradient systems. Journal of Hydrology, 519: 3275-3289. DOI:10.1016/j.jhydrol.2014.10.027

Kamtchueng, B.T., Fantong, W.Y., Wirmvem, M.J., Tiodjio, R.E., Takounjou, A.F., Asai, K., Djomou, S.L.B., Kusakabe, M., Ohba, T., Tanyileke, G., Hell, J.V., Ueda, A., 2015. A multitracer approach for assessing the origin, apparent age and recharge mechanism of shallow groundwater in the Lake Nyos catchment, Northwest, Cameroon. Journal of Hydrology, 523: 790-803. DOI:10.1016/j.jhydrol.2015.02.008

Kashiwaya, K., Hasegawa, T., Nakata, K., Tomioka, Y., Mizuno, T., 2014. Multiple tracer study in Horonobe, northern Hokkaido, Japan: 1. Residence time estimation based on multiple environmental tracers and lumped parameter models. Journal of Hydrology, 519: 532-548. DOI:10.1016/j.jhydrol.2014.07.025

Kelly, J.L., Glenn, C.R., 2015. Chlorofluorocarbon apparent ages of groundwaters from west Hawaii, USA. Journal of Hydrology, 527: 355-366. DOI:10.1016/j.jhydrol.2015.04.069

Koh, D.-C., Plummer, L.N., Busenberg, E., Kim, Y., 2007. Evidence for terrigenic SF6 in groundwater from basaltic aquifers, Jeju Island, Korea: Implications for groundwater dating. Journal of Hydrology, 339: 93-104. DOI:10.1016/j.jhydrol.2007.03.011

La Salle, C.L.G., Aquilina, L., Fourre, E., Jean-Baptiste, P., Michelot, J.-L., Roux, C., Bugai, D., Labasque, T., Simonucci, C., Van Meir, N., Noret, A., Bassot, S., Dapoigny, A., Baumier, D., Verdoux, P., Stammose, D., Lancelot, J., 2012. Groundwater residence time downgradient of Trench No. 22 at the Chernobyl Pilot Site: Constraints on hydrogeological aquifer functioning. Applied Geochemistry, 27: 1304-1319. DOI:10.1016/j.apgeochem.2011.12.006

Labasque, Ayraud, Aquilina, Corre, L., 2006. Dosage des compsés chlorofluorocarbonatés et du tétrachlorure de carbone dans les eaux souterraines. Application à la datation des eaux. Cahiers techniques de Géosciences Rennes. No. 4.

Labasque, T., Aquilina, L., Vergnaud, V., Barbecot, F., 2014. Inter-laboratory comparison of the analyses of sulphur hexafluoride (SF6) and three chlorofluorocarbons (CFC-11,-12 and-113) in groundwater and an air standard. Applied Geochemistry, 50: 118-129.

DOI:10.1016/j.apgeochem.2014.03.009

Lee, J.-Y., 2014. Use of environmental and applied tracers for groundwater studies in Korea. Geosciences Journal, 18: 115-123. DOI:10.1007/s12303-013-0050-y

Longinelli, A., Selmo, E., 2003. Isotopic composition of precipitation in Italy: a first overall map. Journal of Hydrology, 270: 75-88.

Maiss, M., Brenninkmeijer, C.a.M., 1998. Atmospheric SF6: Trends, sources, and prospects. Environmental Science \& Technology, 32: 3077-3086. DOI:10.1021/es9802807

Małoszewski, P., Zuber, A., 1982. Determining the turnover time of groundwater systems with the aid of environmental tracers: 1. Models and their applicability. Journal of Hydrology, 57: 207231. DOI:10.1016/0022-1694(82)90147-0 
Manca, F., Capelli, G., Tuccimei, P., 2015. Sea salt aerosol groundwater salinization in the Litorale Romano Natural Reserve (Rome, Central Italy). Environmental Earth Sciences, 73: 41794190. DOI:10.1007/s12665-014-3704-9

McCallum, J.L., Engdahl, N.B., Ginn, T.R., Cook, P.G., 2014. Nonparametric estimation of groundwater residence time distributions: What can environmental tracer data tell us about groundwater residence time? Water Resources Research, 50: 2022-2038. DOI:10.1002/2013WR014974

Murgulet, D., Cook, M., Murgulet, V., 2016. Groundwater mixing between different aquifer types in a complex structural setting discerned by elemental and stable isotope geochemistry. Hydrological Processes, 30: 410-423.

Orsini, J.-B., Ferrandini, J., Ferrandini, M., Loÿe, M.-D., Pluquet, F., Guennoc, P., Thinon, I., Santiago, M., Reynaud, J.-Y., Oggiano, G., Cherchi, G., Gattaccaca, J., Orrù, P., Puliga, G., Pintus, M., Ulzega, A., 2010. Notice explicative, carte géol. France (1/50 000), feuille SottaBonifacio-Santa-Teresa-di-Gallura (1127), in press. BRGM, Orléans, pp. 258.

Ottaviani-Spella, M.M., Girard, M., Rochette, P., Cheilletz, A., Thinon, M., 2001. Burdigalian volcanism in southern Corsica: petrology, K-Ar dating, palaeomagnetism. Comptes Rendus De L Academie Des Sciences Serie Ii Fascicule a-Sciences, 333: 113-120. DOI:10.1016/S1251-8050(01)01614-7

Penna, D., Stenni, B., Sanda, M., Wrede, S., Bogaard, T.A., Gobbi, A., Borga, M., Fischer, B.M.C., Bonazza, M., Charova, Z., 2010. On the reproducibility and repeatability of laser absorption spectroscopy measurements for delta $\mathrm{H}-2$ and delta O-18 isotopic analysis. Hydrology and Earth System Sciences, 14: 1551-1566. DOI:10.5194/hess-14-1551-2010

Petalas, C., Lambrakis, N., 2006. Simulation of intense salinization phenomena in coastal aquifers the case of the coastal aquifers of Thrace. Journal of Hydrology, 324: 51-64. DOI:10.1016/j.jhydrol.2005.09.031

Plummer, L.N., Busenberg, E., Bohlke, J.K., Nelms, D.L., Michel, R.L., Schlosser, P., 2001. Groundwater residence times in Shenandoah National Park, Blue Ridge Mountains, Virginia, USA: a multi-tracer approach. Chemical Geology, 179: 93-111. DOI:10.1016/S00092541(01)00317-5

Plummer, L.N., Eggleston, J.R., Andreasen, D.C., Raffensperger, J.P., Hunt, A.G., Casile, G.C., 2012. Old groundwater in parts of the upper Patapsco aquifer, Atlantic Coastal Plain, Maryland, USA: evidence from radiocarbon, chlorine-36 and helium-4. Hydrogeology Journal, 20: 12691294. DOI:10.1007/s10040-012-0871-1

Post, V.E.A., Vandenbohede, A., Werner, A.D., Maimun, Teubner, M.D., 2013. Groundwater ages in coastal aquifers. Advances in Water Resources, 57: 1-11. DOI:10.1016/j.advwatres.2013.03.011

Rail, C.D., 2000. Groundwater Contamination: Sources and Hydrology. CRC Press, 214 pp.

Reynaud, J.-Y., Ferrandini, M., Ferrandini, J., Santiago, M., Thinon, I., André, J.-P., Barthet, Y., Guennoc, P., Tessier, B., 2012. From non-tidal shelf to tide-dominated strait: The Miocene Bonifacio Basin, Southern Corsica. Sedimentology, 60: 599-623. DOI:10.1111/j.13653091.2012.01352.x

Rossi, P., 1987. Organisation et genese d'un grand batholite orogénique - Le batholite calco-alcalin de la Corse. Thèse de Doctorat d'Etat, Université de Toulouse Paul Sabatier. . 267p.

Santoni, S., 2013. Etude du fonctionnement hydrogéologique de l'aquifère de Bonifacio à l'aide d'outils isotopiques et géochimiques. Rapport de stage de recherche, Master 2 "Sciences de l'Eau et de l'Environnement", Université de Corse, France.

Schwientek, M., Maloszewski, P., Einsiedl, F., 2009. Effect of the unsaturated zone thickness on the distribution of water mean transit times in a porous aquifer. Journal of Hydrology, 373: 516526. DOI:10.1016/j.jhydrol.2009.05.015

Sivan, O., Yechieli, Y., Herut, B., Lazar, B., 2005. Geochemical evolution and timescale of seawater intrusion into the coastal aquifer of Israel. Geochimica Et Cosmochimica Acta, 69: 579-592. DOI:10.1016/j.gca.2004.07.023 
Spurlock, F., Burow, K., Dubrovsky, N., 2000. Chlorofluorocarbon dating of herbicide-containing well waters in Fresno and Tulare counties, California. Journal of Environmental Quality, 29: 474-483.

Stuart, M.E., Maurice, L., Heaton, T.H.E., Sapiano, M., Sultana, M.M., Gooddy, D.C., Chilton, P.J., 2010. Groundwater residence time and movement in the Maltese islands - A geochemical approach. Applied Geochemistry, 25: 609-620. DOI:10.1016/j.apgeochem.2009.12.010

Suckow, A., 2014. The age of groundwater - Definitions, models and why we do not need this term. Applied Geochemistry, 50: 222-230. DOI:10.1016/j.apgeochem.2014.04.016

Thatcher, Janzer, Edwards, 1977. Methods For Determination of Radioactive Substances in Water and Fluvial Sediments. U.S. Geol. Surv.: pp. 79-81.

Tomassetti, L., Bosellini, F.R., Brandano, M., 2012. Growth and demise of a Burdigalian coral bioconstruction on a granite rocky substrate (Bonifacio Basin, southeastern Corsica). Facies, 59: 703-716. DOI:10.1007/s10347-012-0341-1

Torgersen, Purtscher, Phillips, Plummer, Sanford, Suckow, 2013. Isotope Methods for Dating Old Groundwater. IAEA Library Cataloguing in Publication Data, Vienna : International Atomic Energy Agency.

Turnadge, C., Smerdon, B.D., 2014. A review of methods for modelling environmental tracers in groundwater: Advantages of tracer concentration simulation. Journal of Hydrology, 519: 3674-3689. DOI:10.1016/j.jhydrol.2014.10.056

Vautour, G., Pinti, D.L., Mejean, P., Saby, M., Meyzonnat, G., Larocque, M., Castro, M.C., Hall, C.M., Boucher, C., Roulleau, E., Barbecot, F., Takahata, N., Sano, Y., 2015. H-3/He-3, C-14 and (U-Th)/He groundwater ages in the St. Lawrence Lowlands, Quebec, Eastern Canada. Chemical Geology, 413: 94-106. DOI:10.1016/j.chemgeo.2015.08.003

Zuber, A., Witczak, S., Różański, K., Śliwka, I., Opoka, M., Mochalski, P., Kuc, T., Karlikowska, J., Kania, J., Jackowicz-Korczyński, M., Duliński, M., 2005. Groundwater dating with 3H and SF6 in relation to mixing patterns, transport modelling and hydrochemistry. Hydrological Processes, 19: 2247-2275. DOI:10.1002/hyp.5669 


\section{List of tables}

Table 1: Type, use, depth, piezometric levels, unsaturated zone thickness and aquifer levels according to the geologic data available.

Table 2: Field parameters, ionic composition of groundwater and seawater, stable isotopes of water and carbon-13 ratios for the May 2013 campaign (- not analysed).

Table 3: ${ }^{3} \mathrm{H}, \mathrm{CFCs}, \mathrm{SF}_{6}$, noble gases, excess air and recharge temperatures in groundwater (not analysed).

Table 4: Mixing rates from binary mixing model, groundwater weighted ages (years) deduced from CFCs and SF6 concentrations and the respective excess in ppty. 


\section{List of figures}

Fig 1: Map of the general geology (simplified from Reynaud et al, 2012), topography and distribution of sampling points. The green symbols are for the boreholes and wells pumping in the upper aquifer. Those in red are for the lower aquifer or located in the granite. Potentiometric contour map is also represented with blue lines, the blue arrows are representing the main flow directions.

Fig 2: Cross section through the Bonifacio basin (from Reynaud et al, 2012, modified), the vertical straight line represents the depth of the boreholes B4, B1, B3, B8, B3, B11 and B7. Piezometric level in each borehole is indicated with the apex of the blue triangle faces downward. The geologic legend is similar to the figure 1.

Fig 3: Piper diagram displaying the evolution of the water type and the increase in mineralisation. Circles radiuses around points are proportional to the electric conductivity (EC). Green symbols are for $\mathrm{UA}_{\mathrm{r}}$ and $\mathrm{UA}_{\mathrm{v}}$ whereas red symbols are for LA and G.

Fig 4: Plots displaying major ions, $\mathrm{Br}^{-}, \mathrm{B}^{+}$and $\mathrm{Ba}^{2+}$ concentrations and their correlation (r). Green triangles up are for $\mathrm{UA}_{\mathrm{r}}$ and $\mathrm{UA}_{\mathrm{v}}$ whereas red triangles down are for LA and $\mathrm{G}$.

Fig 5: ${ }^{2} \mathrm{H}$ vs ${ }^{18} \mathrm{O}$ plot of all the groundwater samples. The mean stable isotopic compositions of the rainwater of Piombino (Tuscany, Italy) and Sassari (Sardinia, Italy) from Longinelli and Selmo (2003) are also plotted. The Bonifacio seawater signature (Santoni, 2013) is plotted in blue. The dotted line and the black line represent the Western Mediterranean Meteoric Water Line (WMMWL) from (Celle-Jeanton et al., 2001) and the Global Meteoric Water Line respectively.

Fig 6: Estimation of groundwater weighted age and flow mechanism for CFC-12 and $\mathrm{SF}_{6}$ concentrations. Green triangles up are for $\mathrm{UA}_{\mathrm{r}}$ and $\mathrm{UA}_{\mathrm{v}}$ whereas red triangles down are for $\mathrm{LA}$ and $\mathrm{G}$. Plots underlined exhibit the higher $\mathrm{SF}_{6}$ excess.

Fig 7: Plots displaying mixing ratios correlations with major ions, $\mathrm{Br}^{-}, \mathrm{B}^{+}$and $\mathrm{Ba}^{2+}$ when greater than 0.50. Green triangles up are for $\mathrm{UA}_{\mathrm{r}}$ and $\mathrm{UA}_{\mathrm{v}}$ whereas red triangles down are for LA and $\mathrm{G}$.

Fig 8: Schematized aquifer functioning deduced from geological, piezometric and hydrochemical data, completed with flow pattern established in this paper. 
Table 1:

\begin{tabular}{|c|c|c|c|c|c|c|c|}
\hline $\begin{array}{l}\text { Sampling } \\
\text { point }\end{array}$ & Type & Exploitation & $\begin{array}{l}\text { Altitude } \\
\text { (m asl) }\end{array}$ & $\begin{array}{l}\text { Depth } \\
(\mathrm{m})\end{array}$ & $\begin{array}{l}\text { Piezometric } \\
\text { Level (m asl) }\end{array}$ & $\begin{array}{c}\text { Unsaturated } \\
\text { zone thickness } \\
(\mathrm{m})\end{array}$ & Aquifer \\
\hline W1 & Well & Private & 24 & 5 & 21.7 & 2.3 & Upper \\
\hline W2 & Well & Drinking water supply & 9 & 15.5 & -0.9 & 10.4 & Upper \\
\hline W3 & Well & Drinking water supply & 3 & 7.5 & 0.1 & 2.8 & Upper \\
\hline W4 & Well & Drinking water supply & 7 & 15.3 & 1.3 & 6.4 & Upper \\
\hline B1 & Borehole & Private & 70 & 127 & 49.3 & 20.2 & Upper \\
\hline B2 & Borehole & Non-exploited & 47 & 44 & 21.0 & 28.0 & Upper \\
\hline B3 & Borehole & Non-exploited & 53 & 90 & 18.0 & 35.4 & Upper \\
\hline B4 & Borehole & Private & 22 & 45 & 19.4 & 2.6 & Upper \\
\hline B5 & Borehole & Non-exploited & 33 & 116 & 12.2 & 21.0 & Upper \\
\hline B6 & Borehole & Private & 76 & 90 & - & - & Upper \\
\hline B7 & Borehole & Non-exploited & 25 & 75 & 16.7 & 9.0 & Upper \\
\hline B8 & Borehole & Non-exploited & 54 & 269 & 10.1 & 43.1 & Lower \\
\hline B9 & Borehole & Private & 75 & 60 & 62.0 & 12.5 & Lower \\
\hline B10 & Borehole & Private & 88 & 120 & 70.8 & 16.4 & Upper \\
\hline B11 & Borehole & Non-exploited & 75 & 160 & 22.2 & 53.0 & Lower \\
\hline B12 & Borehole & Private & 34 & 100 & 31.4 & 2.3 & Granitic \\
\hline B13 & Borehole & Private & 14 & 160 & 10.0 & 3.6 & Granitic \\
\hline
\end{tabular}


Table 2:

\begin{tabular}{|c|c|c|c|c|c|c|c|c|c|c|c|c|c|c|c|c|c|c|c|c|c|}
\hline \multirow[t]{2}{*}{$\begin{array}{l}\text { Sampling } \\
\text { point }\end{array}$} & \multirow[t]{2}{*}{$\begin{array}{c}\mathrm{T} \\
\left({ }^{\circ} \mathrm{C}\right)\end{array}$} & \multirow[t]{2}{*}{$\mathrm{pH}$} & \multirow[t]{2}{*}{$\begin{array}{c}\mathrm{EC} \\
(\mu \mathrm{S} / \mathrm{cm})\end{array}$} & \multirow[t]{2}{*}{$\begin{array}{c}\text { TDS } \\
(\mathrm{mg} / \mathrm{L})\end{array}$} & \multirow[t]{2}{*}{$\begin{array}{l}\mathrm{HCO}_{3}^{-} \\
(\mathrm{mg} / \mathrm{L})\end{array}$} & \multirow[t]{2}{*}{$\begin{array}{c}\mathrm{Cl}^{-} \\
(\mathrm{mg} / \mathrm{L})\end{array}$} & \multirow[t]{2}{*}{$\begin{array}{c}\mathrm{NO}_{3}^{-} \\
(\mathrm{mg} / \mathrm{L})\end{array}$} & \multirow[t]{2}{*}{$\begin{array}{l}\mathrm{SO}_{4}{ }^{2-} \\
(\mathrm{mg} / \mathrm{L})\end{array}$} & \multirow[t]{2}{*}{$\begin{array}{c}\mathrm{Na}^{+} \\
(\mathrm{mg} / \mathrm{L})\end{array}$} & \multirow[t]{2}{*}{$\begin{array}{c}\mathrm{K}^{+} \\
(\mathrm{mg} / \mathrm{L})\end{array}$} & \multirow[t]{2}{*}{$\begin{array}{c}\mathrm{Mg}^{2+} \\
(\mathrm{mg} / \mathrm{L})\end{array}$} & \multirow[t]{2}{*}{$\begin{array}{c}\mathrm{Ca}^{2+} \\
(\mathrm{mg} / \mathrm{L})\end{array}$} & \multirow[t]{2}{*}{$\begin{array}{c}\text { Charge } \\
\text { Balance } \\
(\%)\end{array}$} & \multirow[t]{2}{*}{$\begin{array}{c}\mathrm{SiO}_{2} \\
(\mathrm{mg} / \mathrm{L})\end{array}$} & \multirow[t]{2}{*}{$\begin{array}{c}\mathrm{Br}^{-} \\
(\mathrm{mg} / \mathrm{L})\end{array}$} & \multirow[t]{2}{*}{$\begin{array}{c}\mathrm{Ba}^{2+} \\
(\mu \mathrm{g} / \mathrm{L})\end{array}$} & \multirow[t]{2}{*}{$\begin{array}{c}\mathrm{B}^{+} \\
(\mu \mathrm{g} / \mathrm{L})\end{array}$} & $\delta^{18} \mathrm{O}$ & $\delta^{2} \mathrm{H}$ & $\begin{array}{c}\text { Excess } \\
d\end{array}$ & \multirow[t]{2}{*}{$\begin{array}{c}\delta^{13} \mathrm{C} \\
(\% \circ \text { vs PDP) }\end{array}$} \\
\hline & & & & & & & & & & & & & & & & & & \multicolumn{3}{|c|}{ (\%o vs VSMOW) } & \\
\hline W1 & 15.4 & 7.3 & 2340 & 1584.4 & 495 & 446.6 & 0.0 & 138.0 & 230.3 & 7.4 & 35.3 & 230.3 & 2 & 10.5 & 1.5 & 20.8 & 123.9 & -5.74 & -35.90 & 11.24 & -15.19 \\
\hline w2 & 17.8 & 7.2 & 999 & 678.0 & 298 & 135.3 & 5.1 & 31.6 & 65.7 & 2.4 & 8.3 & 131.2 & 4 & 9.4 & 0.4 & 6.8 & 59.0 & -6.09 & -37.49 & 10.08 & -13.29 \\
\hline W3 & 17.7 & 7.1 & 1093 & 788.3 & 375 & 136.0 & 5.7 & 37.0 & 73.3 & 3.3 & 9.5 & 148.0 & 3 & 16.4 & 0.5 & 10.3 & 76.7 & -6.04 & -36.99 & 8.51 & -13.36 \\
\hline W4 & 17.4 & 7.1 & 1214 & 860.3 & 381 & 172.9 & 11.6 & 34.9 & 96.5 & 2.9 & 13.5 & 146.5 & 3 & 11.5 & 0.6 & 9.1 & 66.2 & -6.14 & -38.16 & 10.98 & -12.21 \\
\hline $\mathrm{B} 1$ & 17.7 & 7.2 & 2050 & 1362.8 & 423 & 377.4 & 39.0 & 94.6 & 169.0 & 3.4 & 25.7 & 229.5 & 2 & 11.3 & 1.1 & 21.3 & 370.2 & -5.53 & -34.13 & 11.34 & -13.02 \\
\hline B2 & 19.1 & 7.3 & 725 & 583.1 & 353 & 51.4 & 6.3 & 10.9 & 42.0 & 3.7 & 7.4 & 108.0 & 2 & 18.9 & 0.3 & 10.0 & 63.0 & -6.04 & -37.21 & 11.24 & -14.25 \\
\hline B3 & 18.8 & 7.0 & 1096 & 800.0 & 381 & 148.0 & 5.6 & 28.4 & 81.4 & 1.8 & 10.0 & 143.2 & 2 & 14.8 & 0.5 & 9.6 & 45.0 & -5.93 & -36.15 & 11.31 & -12.82 \\
\hline B4 & 17.7 & 7.1 & 1955 & 1322.6 & 444 & 355.6 & 17.7 & 95.1 & 199.5 & 5.7 & 29.1 & 174.8 & 1 & 13.5 & 1.1 & 21.6 & 134.5 & -5.67 & -35.23 & 10.02 & -12.98 \\
\hline B5 & 18.8 & 7.2 & 1084 & 783.1 & 421 & 154.5 & 1.5 & 6.5 & 74.2 & 2.6 & 11.9 & 110.3 & -5 & - & 0.5 & 4.8 & 59.2 & -6.03 & -36.95 & 11.29 & -10.68 \\
\hline B6 & 17.9 & 7.2 & 1257 & 885.0 & 371 & 205.6 & 7.7 & 33.3 & 120.2 & 4.0 & 16.8 & 125.6 & 1 & 10.0 & 0.7 & 9.5 & 88.4 & -5.74 & -35.63 & 11.12 & -12.73 \\
\hline B7 & 18.4 & 7.0 & 1038 & 805.6 & 416 & 124.8 & 4.7 & 29.7 & 74.6 & 3.2 & 13.2 & 139.0 & 1 & 13.8 & 0.5 & 9.9 & 66.3 & -6.08 & -37.12 & 11.49 & -13.16 \\
\hline B8 & 18.3 & 7.0 & 1073 & 788.7 & 398 & 140.0 & 0.0 & 23.7 & 80.0 & 1.1 & 10.1 & 135.4 & 3 & 15.0 & 0.4 & 8.8 & 40.0 & -5.93 & -36.33 & 11.08 & -12.71 \\
\hline B9 & 18.9 & 7.1 & 1676 & 1092.1 & 365 & 328.3 & 8.4 & 43.4 & 182.4 & 5.4 & 25.3 & 132.7 & 1 & 9.9 & 1.0 & 21.5 & 115.8 & -4.79 & -29.82 & 10.58 & -11.85 \\
\hline B10 & 17.9 & 6.7 & 2070 & 1476.8 & 577 & 340.5 & 34.6 & 76.8 & 170.0 & 2.9 & 19.8 & 254.0 & 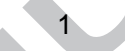 & 16.3 & 1.3 & 18.4 & 102.5 & -5.95 & -36.37 & 10.55 & -14.01 \\
\hline B11 & 20.1 & 7.2 & 1056 & 704.4 & 316 & 139.4 & 4.9 & 22.4 & 88.0 & 3.4 & 13.4 & 116.4 & 5 & 17.8 & 0.5 & 8.6 & 65.9 & -5.93 & -34.91 & 12.49 & -13.62 \\
\hline B12 & 17.6 & 7.3 & 1405 & 950.2 & 355 & 232.2 & 0.0 & 57.9 & 213.5 & 4.3 & 24.8 & 61.4 & 3 & 15.3 & 0.7 & 58.2 & 171.7 & -5.66 & -34.72 & 12.72 & -16.89 \\
\hline B13 & 17.2 & 7.0 & 2130 & 1316.5 & 287 & 492.3 & 0.0 & 105.5 & 283.2 & 4.7 & 30.6 & 111.8 & -1 & 11.2 & 1.5 & 133.6 & 185.4 & -6.34 & -37.96 & 10.14 & -15.43 \\
\hline Seawater & 18.1 & 8.23 & 56800 & 38482 & 150 & 20760 & 0.0 & 2799 & 12234 & 437 & 1590 & 441 & 4 & - & 71 & - & - & 1.07 & 4.78 & -3.82 & - \\
\hline
\end{tabular}


Table 3:

\begin{tabular}{|c|c|c|c|c|c|c|c|c|c|c|c|c|c|c|}
\hline \multirow[t]{2}{*}{ Sampling point } & \multirow{2}{*}{$\begin{array}{l}{ }^{3} \mathrm{H} \\
(\mathrm{TU})\end{array}$} & \multicolumn{2}{|c|}{ CFC-11 } & \multicolumn{2}{|c|}{ CFC-12 } & \multicolumn{2}{|c|}{ CFC-113 } & \multicolumn{2}{|l|}{$\mathrm{SF}_{6}$} & \multirow{2}{*}{$\begin{array}{c}\mathrm{Ne} \\
\text { (CCSTP) }\end{array}$} & \multirow{2}{*}{$\begin{array}{c}\mathrm{Ar} \\
\text { (CCSTP) }\end{array}$} & \multicolumn{2}{|c|}{ Excess air } & \multirow{2}{*}{$\begin{array}{l}\text { Recharge } \\
\text { temp. } \\
\left({ }^{\circ} \mathrm{C}\right)\end{array}$} \\
\hline & & $(\mathrm{pmol} / \mathrm{Kg})$ & (pptv) & $(\mathrm{pmol} / \mathrm{Kg})$ & (pptv) & $(\mathrm{pmol} / \mathrm{Kg})$ & (pptv) & $(\mathrm{pmol} / \mathrm{Kg})$ & (pptv) & & & $\left(\mathrm{cm}^{3} \mathrm{STP} / \mathrm{g}\right)$ & $(\mathrm{mL} / \mathrm{L})$ & \\
\hline W1 & $3.4( \pm 0.3)$ & $6,51 \mathrm{E}-01$ & 48 & $2,08 \mathrm{E}+00$ & 546 & $2,59 \mathrm{E}-01$ & 74 & $2,26 \mathrm{E}-03$ & 7.96 & $2,330 \mathrm{E}-07$ & $3,735 \mathrm{E}-04$ & $4,58 \mathrm{E}-03$ & 4,58 & 16,3 \\
\hline W2 & $3.4( \pm 0.2)$ & $6,73 \mathrm{E}-01$ & 46 & 3,13E-01 & 120 & $7,00 \mathrm{E}-02$ & 6 & $3,20 \mathrm{E}-04$ & 1.13 & $1,858 \mathrm{E}-07$ & $3,108 \mathrm{E}-04$ & $-9,21 \mathrm{E}-04$ & $-0,92$ & 16,2 \\
\hline W3 & $1.5( \pm 0.3)$ & $1,25 \mathrm{E}+00$ & 66 & $1,65 \mathrm{E}+00$ & 108 & $7,62 \mathrm{E}-01$ & 43 & $1,65 \mathrm{E}-03$ & 2.10 & 2,353E-07 & 3,388E-04 & 2,04E-03 & 2,04 & 16,9 \\
\hline W4 & $3.5( \pm 0.4)$ & $1,32 \mathrm{E}+00$ & 95 & $8,96 \mathrm{E}-01$ & 243 & 3,34E-01 & 83 & $5,33 \mathrm{E}-04$ & 1.89 & $2,183 \mathrm{E}-07$ & $3,227 \mathrm{E}-04$ & 3,36E-03 & 3,36 & 19,4 \\
\hline B1 & $2.6( \pm 0.4)$ & $3,48 \mathrm{E}+00$ & 255 & $2,07 \mathrm{E}+00$ & 512 & $5,06 \mathrm{E}-01$ & 125 & $1,90 \mathrm{E}-03$ & 6.72 & 1,495E-07 & 2,927E-04 & $-1,53 \mathrm{E}-03$ & $-1,53$ & 16,6 \\
\hline B2 & $2.6( \pm 0.4)$ & $3,15 E+00$ & 231 & $1,54 \mathrm{E}+00$ & 443 & $4,74 \mathrm{E}-01$ & 160 & $1,61 \mathrm{E}-03$ & 5.70 & $1,625 \mathrm{E}-07$ & 2,779E-04 & $-9,22 \mathrm{E}-04$ & $-0,92$ & 21,2 \\
\hline B3 & $5.7( \pm 0.4)$ & $1,76 \mathrm{E}+00$ & 78 & $1,84 \mathrm{E}+00$ & 159 & $2,88 \mathrm{E}-01$ & 25 & $4,00 \mathrm{E}-04$ & 1.41 & $1,732 \mathrm{E}-07$ & $3,256 \mathrm{E}-04$ & -3,92E-04 & $-0,39$ & 16,4 \\
\hline B4 & $2.1( \pm 0.3)$ & $1,12 \mathrm{E}+00$ & 82 & $1,06 \mathrm{E}+00$ & 287 & $2,34 \mathrm{E}-02$ & 6 & $1,01 \mathrm{E}-03$ & 3.57 & 2,936E-07 & $4,004 \mathrm{E}-04$ & 6,67E-03 & 6,66 & 15,2 \\
\hline B5 & $1.4( \pm 0.2)$ & $3,46 \mathrm{E}+00$ & 234 & $1,99 \mathrm{E}+00$ & 539 & $9,16 \mathrm{E}-02$ & 23 & $1,97 \mathrm{E}-04$ & 0.70 & $2,667 \mathrm{E}-07$ & $3,814 \mathrm{E}-04$ & $6,13 \mathrm{E}-03$ & 6,13 & 16,5 \\
\hline B6 & $1.7( \pm 0.2)$ & $1,61 \mathrm{E}+00$ & 118 & $1,19 \mathrm{E}+00$ & 328 & 2,20E-01 & 54 & $5,44 \mathrm{E}-04$ & 1.92 & $1,925 \mathrm{E}-07$ & 3,021E-04 & 3,44E-03 & 3,43 & 17,0 \\
\hline B7 & $2.3( \pm 0.4)$ & $1,33 \mathrm{E}+00$ & 89 & $9,27 \mathrm{E}-01$ & 238 & $1,91 \mathrm{E}-02$ & 5 & $2,06 \mathrm{E}-03$ & 7.37 & 2,263E-07 & $3,256 \mathrm{E}-04$ & $2,86 \mathrm{E}-03$ & 2,85 & 19,4 \\
\hline B8 & $4.8( \pm 0.4)$ & $8,74 \mathrm{E}-01$ & 53 & $6,03 \mathrm{E}-01$ & 141 & $5,25 \mathrm{E}-02$ & 24 & $6,58 \mathrm{E}-04$ & 4.93 & $1,826 \mathrm{E}-07$ & 3,222E-04 & $-1,94 \mathrm{E}-04$ & $-0,19$ & 17,5 \\
\hline B9 & $3.0( \pm 0.5)$ & $6,71 \mathrm{E}-01$ & 49 & $4,51 \mathrm{E}-01$ & 131 & $6,84 \mathrm{E}-02$ & 55 & $2,00 \mathrm{E}-03$ & 7.05 & $2,037 \mathrm{E}-07$ & 3,397E-04 & 1,73E-03 & 1,73 & 17,2 \\
\hline B10 & $3.9( \pm 0.7)$ & $2,41 \mathrm{E}+00$ & 171 & $1,85 \mathrm{E}+00$ & 522 & $2,61 \mathrm{E}-01$ & 63 & $6,03 \mathrm{E}-04$ & 2.13 & $2,136 \mathrm{E}-07$ & 3,482E-04 & $2,85 \mathrm{E}-03$ & 2,85 & 17,3 \\
\hline B11 & $<0.5$ & $1,40 \mathrm{E}-01$ & 9 & $6,66 \mathrm{E}-02$ & 16 & $2,35 \mathrm{E}-02$ & 5 & 1,03E-03 & 3.29 & & & & & \\
\hline B12 & $3.2( \pm 0.4)$ & $1,16 \mathrm{E}+00$ & 85 & $1,08 \mathrm{E}+00$ & 347 & $1,75 \mathrm{E}-01$ & 49 & $2,42 \mathrm{E}-03$ & 8.59 & $2,801 \mathrm{E}-07$ & 3,671E-04 & $4,85 \mathrm{E}-03$ & 4,84 & 17,0 \\
\hline B13 & $1.7( \pm 0.2)$ & $3,40 \mathrm{E}-01$ & 22 & $1,09 \mathrm{E}+00$ & 294 & $1,64 \mathrm{E}-02$ & 4 & $5,38 \mathrm{E}-03$ & 18.37 & 1,779E-07 & 3,585E-04 & $1,59 \mathrm{E}-03$ & 1,59 & 15,6 \\
\hline
\end{tabular}


Table 4:

\begin{tabular}{cccc}
\hline $\begin{array}{c}\text { Sampling } \\
\text { point }\end{array}$ & $\begin{array}{c}\text { Binary Mixing Model } \\
\text { (\% young water) }\end{array}$ & $\begin{array}{c}\text { Groundwater weighted } \\
\text { residence times (years) }\end{array}$ & $\begin{array}{c}\text { SF6 excess } \\
\text { (pptv) }\end{array}$ \\
\hline W1 & $100 \%$ & 9 & 0.00 \\
W2 & $20 \%$ & 52 & 0.90 \\
W3 & $20 \%$ & 52 & 1.88 \\
W4 & $45 \%$ & 39 & 1.47 \\
B1 & $90-95 \%$ & 13 & 4.28 \\
B2 & $85 \%$ & 17 & 3.91 \\
B3 & $30 \%$ & 47 & 1.13 \\
B4 & $50 \%$ & 36 & 3.31 \\
B5 & $15-30 \%$ & 51 & 0.00 \\
B6 & $60 \%$ & 31 & 0.00 \\
B7 & $45 \%$ & 39 & 6.98 \\
B8 & $25 \%$ & 50 & 4.68 \\
B9 & $25 \%$ & 50 & 7.05 \\
B10 & $90 \%$ & 14 & 0.00 \\
B11 & $<5 \%$ & 60 & 3.29 \\
B12 & $55-65 \%$ & 36 & 8.59 \\
B13 & $40-45 \%$ & 40 & 18.37 \\
\hline
\end{tabular}




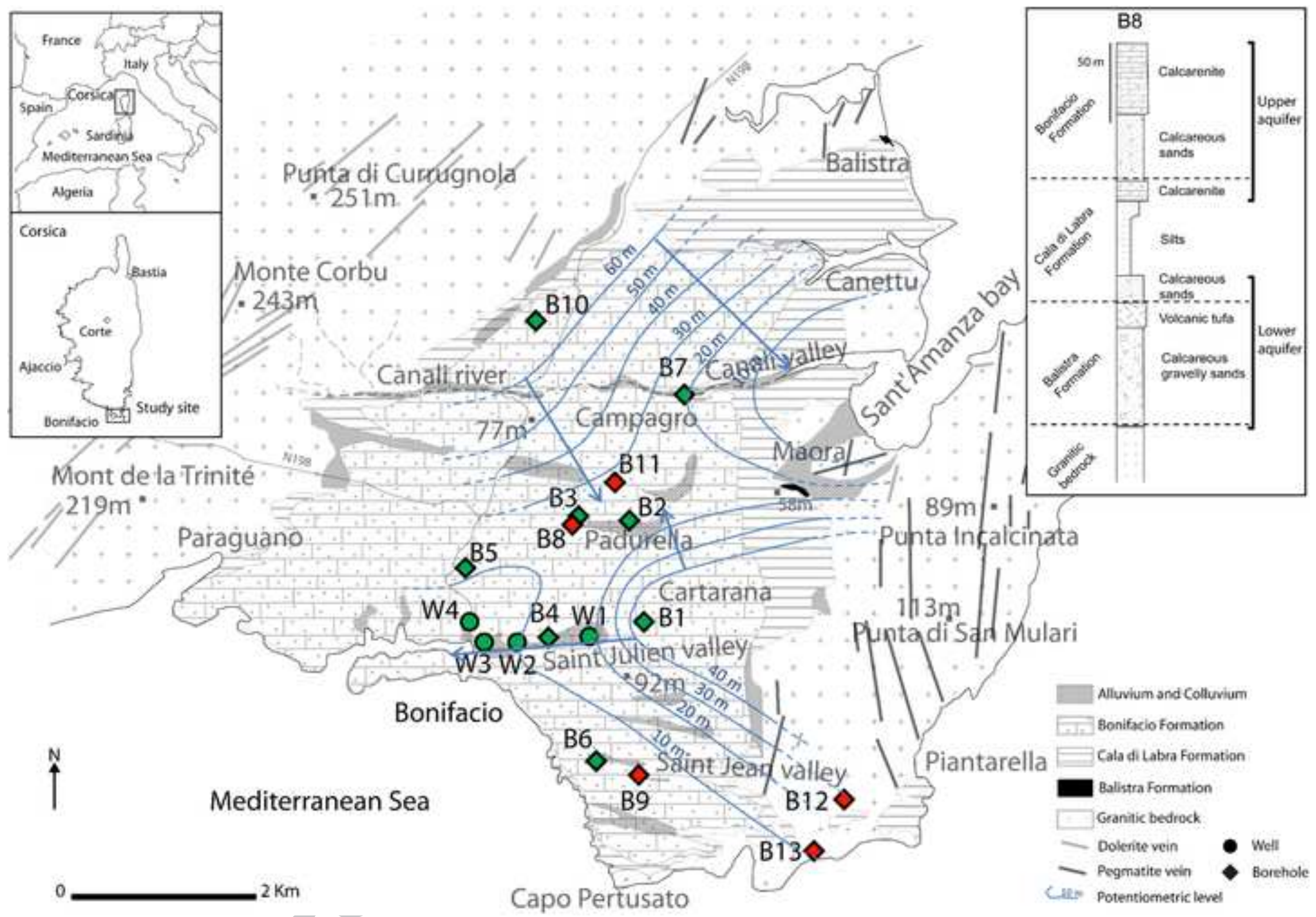




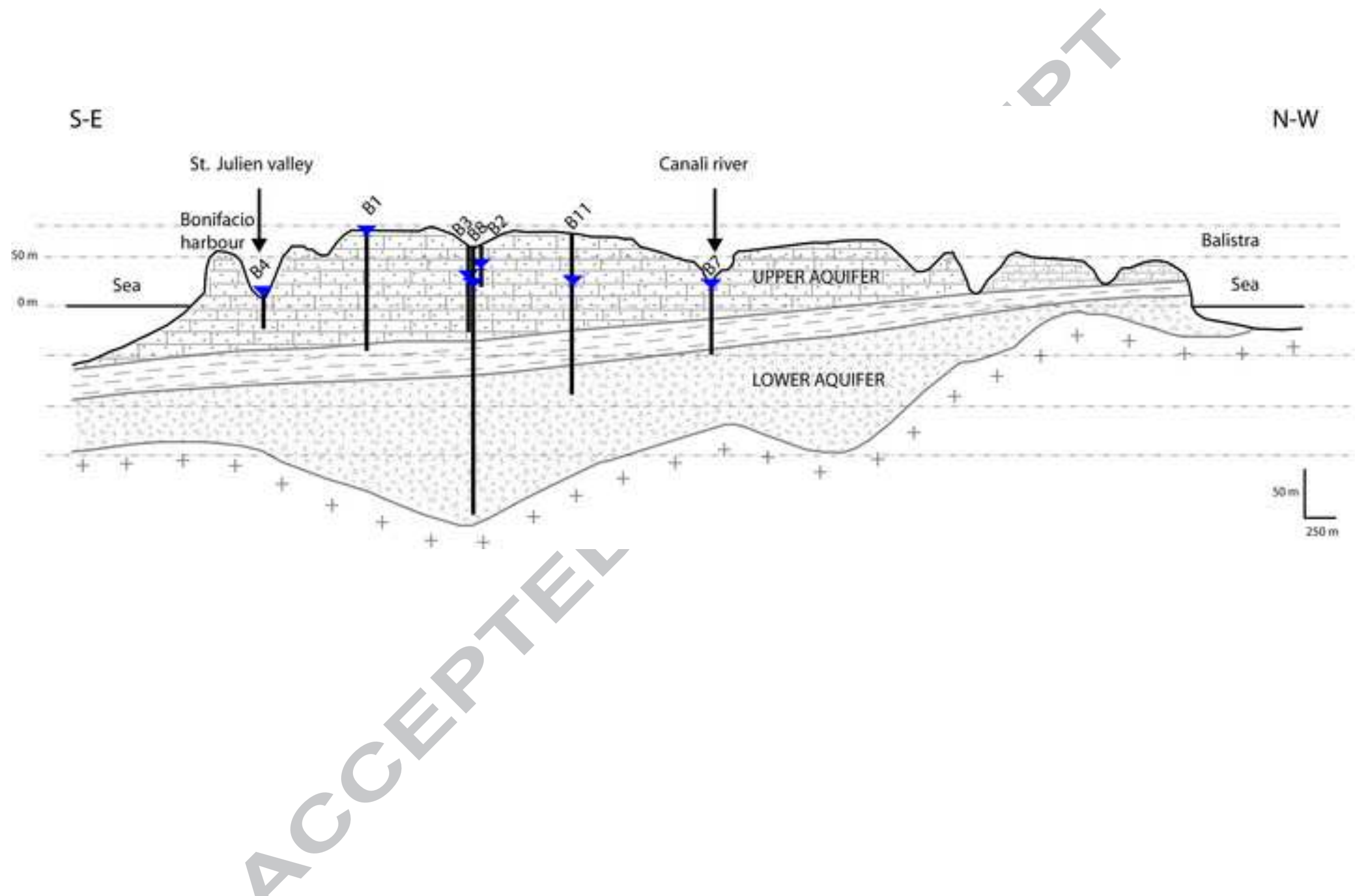




\section{ACCEPTED MANUSCRIPT}

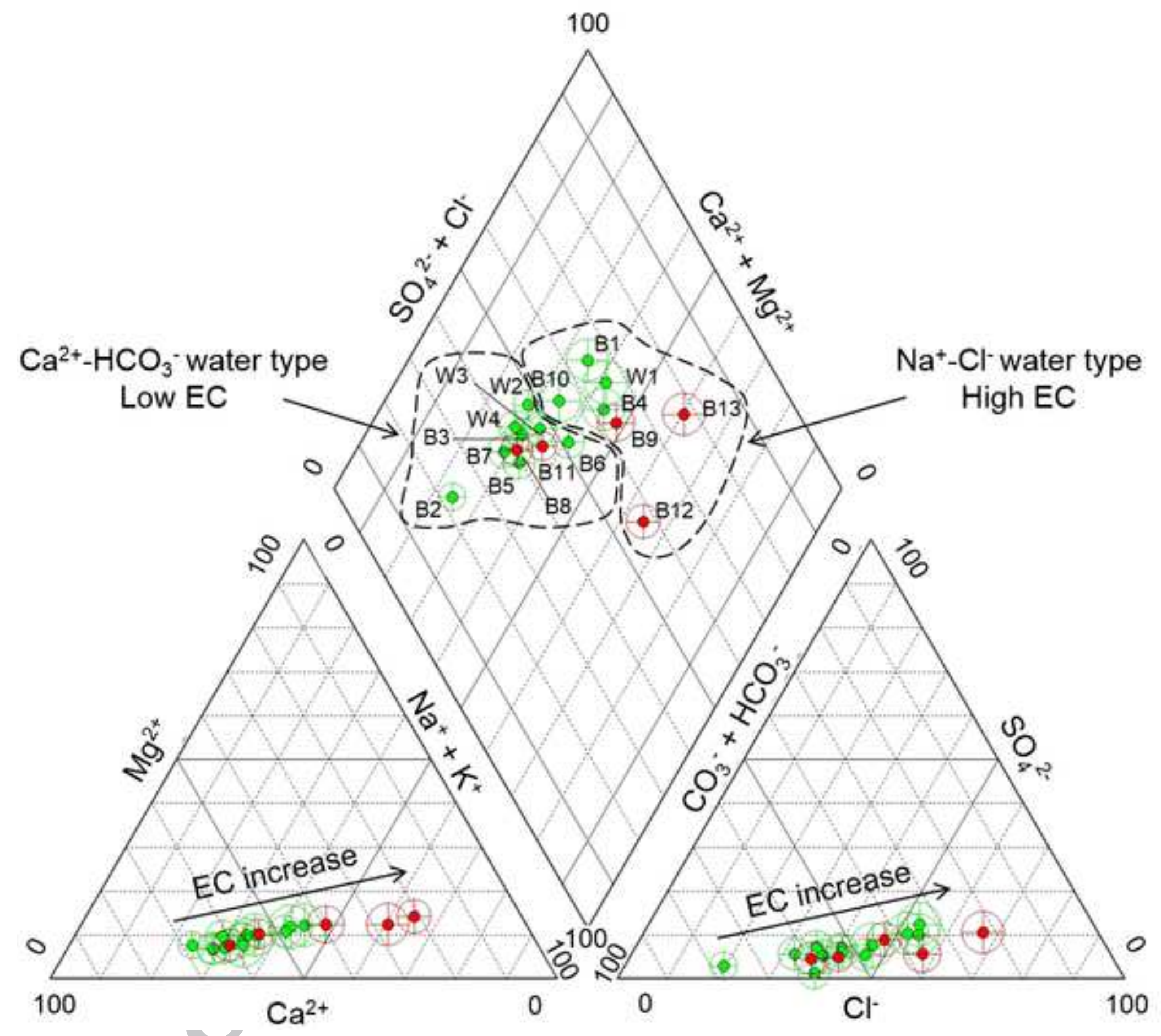



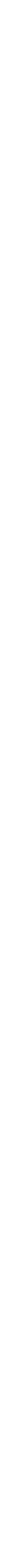


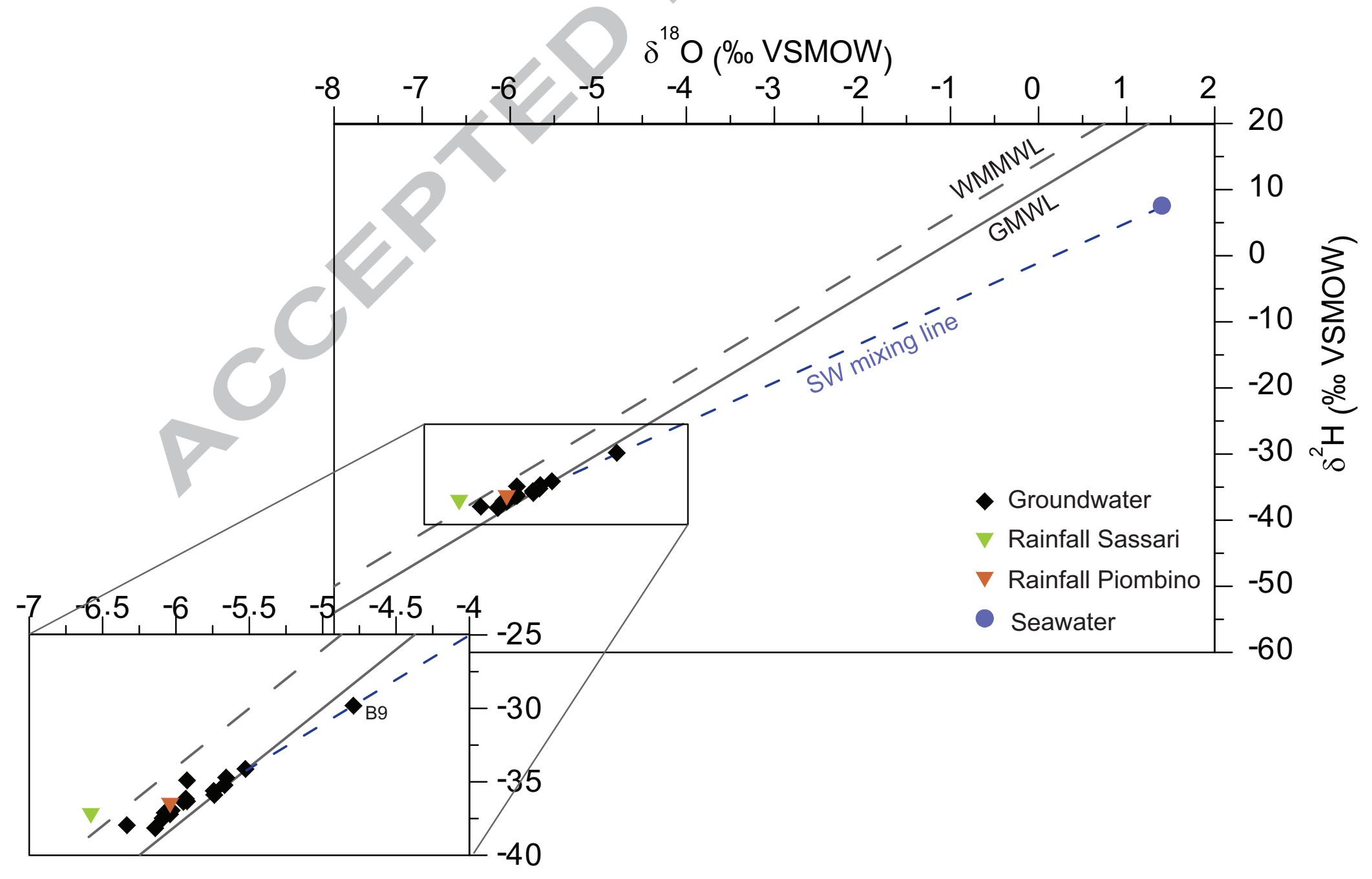




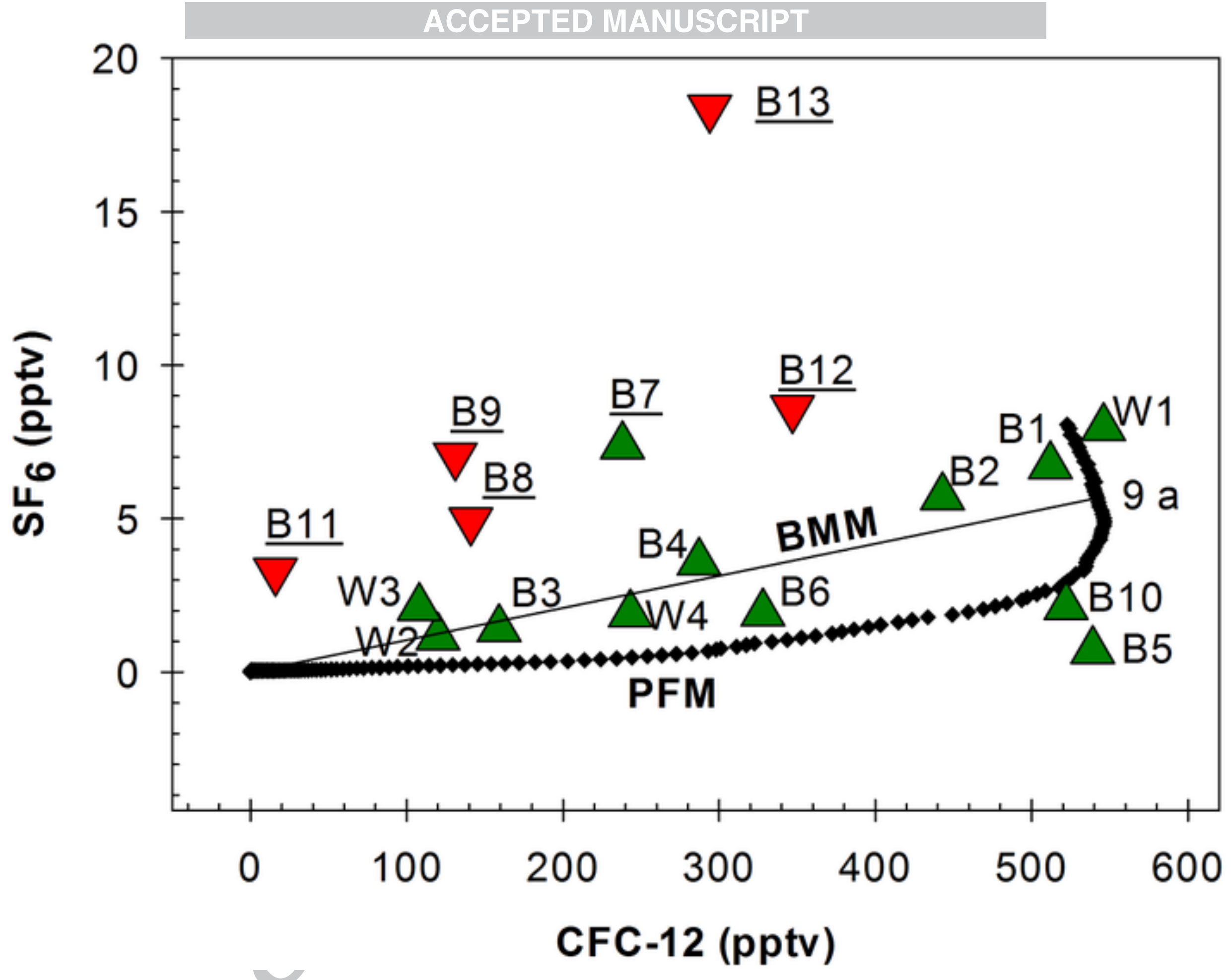



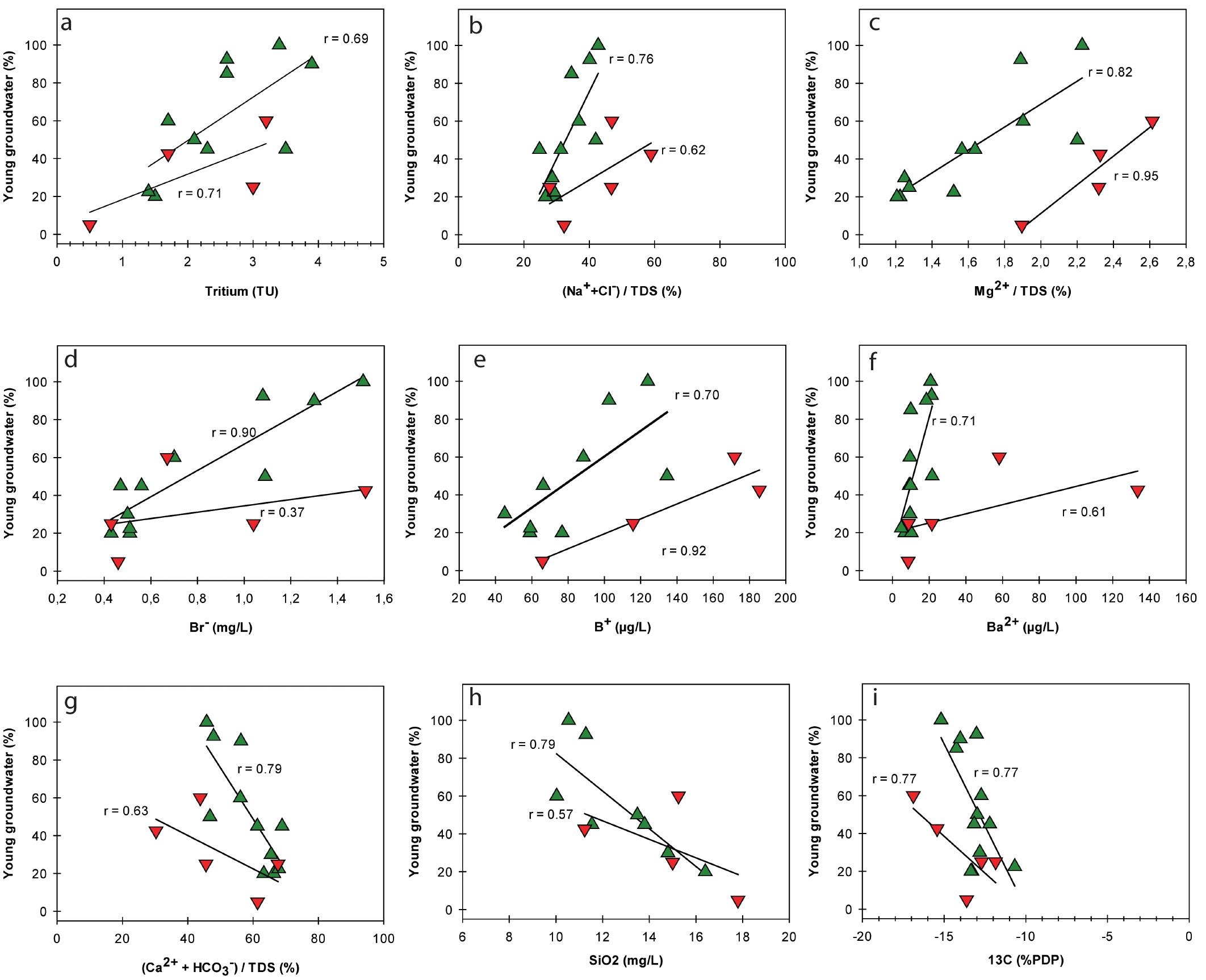


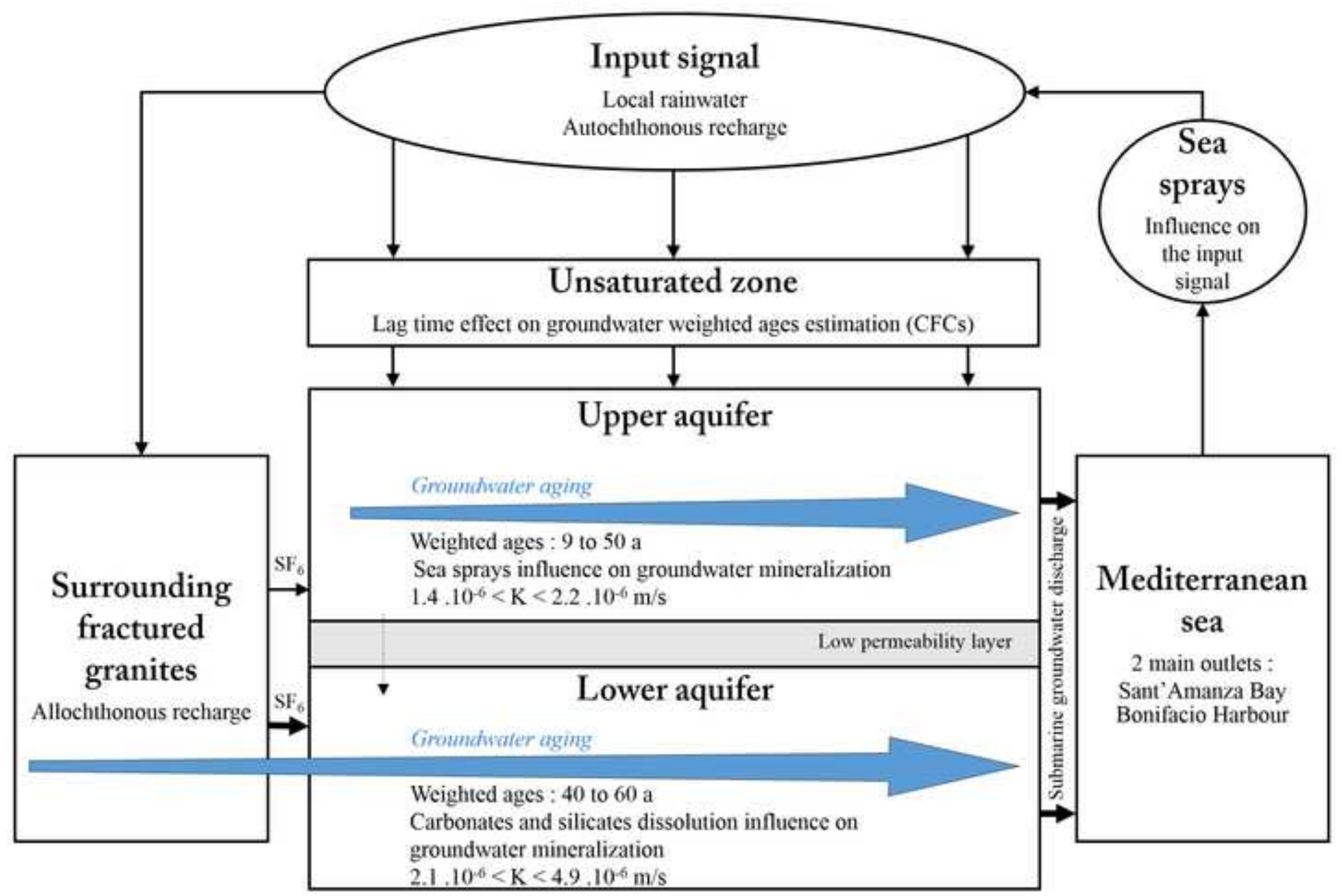




\section{$\underline{\text { Highlights }}$}

- CFCs and $\mathrm{SF}_{6}$ were used to evaluate groundwater residence time in a coastal aquifer

- CFCs can be used for carbonate aquifers with deep unsaturated zone

- Natural $\mathrm{SF}_{6}$ found in granites can constitute a direct tracer of groundwater origin 